\title{
CIDA: A collective inquiry framework to study and support teachers as designers in technological environments
}

\author{
Konstantinos Michosa,b*, Davinia Hernández-Leo \\ aDepartment of Information and Communication Technologies, Universitat Pompeu Fabra, Roc \\ Boronat 138, 08018 Barcelona, Spain, \\ (kostas.michos, davinia.hernandez-leo) dupf.edu \\ ${ }^{\mathrm{b}}$ School of Telecommunications Engineering, Universidad de Valladolid, Paseo de Belén 15, \\ 47011 Valladolid, Spain
}

\begin{abstract}
The use of new technologies such as learning analytics by teachers is challenging due to the changes they bring to teachers' practices and their pedagogical interventions. A design approach into teaching has been proposed for mapping pedagogy with technology to effectively integrate these changes. However, limited collective approaches exist in which teachers participate in professional communities to build knowledge for the design and implementation of learning scenarios with learning analytics. In this paper, we propose a framework (CIDA) for collective inquiry in such professional communities of teachers. Based on other collective inquiry frameworks for knowledge building, we propose three interconnected components: the inquiry process, the collective process, and technological support to facilitate and study teachers' design practices in technological environments. We explain the framework with examples of implemented technologies and present empirical results of three cases; two High schools and a Massive Open Online Course (MOOC). Results inform further how our framework can be implemented in practice and its required supports to facilitate knowledge building for inquiry communities of teachers.
\end{abstract}

Keywords: learning communities; lifelong learning; teaching/learning strategies; distributed learning environments; improving classroom teaching

*Corresponding author. E-mail: kostas.michos@upf.edu 


\title{
CIDA: A collective inquiry framework to study and support teachers as designers in technological environments
}

\begin{abstract}
The use of new technologies such as learning analytics by teachers is challenging due to the changes they bring to teachers' practices and their pedagogical interventions. A design approach into teaching has been proposed for mapping pedagogy with technology to effectively integrate these changes. However, limited collective approaches exist in which teachers participate in professional communities to build knowledge for the design and implementation of learning scenarios with learning analytics. In this paper, we propose a framework (CIDA) for collective inquiry in such professional communities of teachers. Based on other collective inquiry frameworks for knowledge building, we propose three interconnected components: the inquiry process, the collective process, and technological support to facilitate and study teachers' design practices in technological environments. We explain the framework with examples of implemented technologies and present empirical results of three cases; two High schools and a Massive Open Online Course (MOOC). Results inform further how our framework can be implemented in practice and its required supports to facilitate knowledge building for inquiry communities of teachers.
\end{abstract}

Keywords: learning communities; lifelong learning; teaching/learning strategies; distributed learning environments; improving classroom teaching

\section{Introduction}

Teacher involvement in designing technology-integrating learning activities has emerged as a challenge with the increasing use of Information and Communication Technology (ICT) in Education. The incorporation of new technologies into teacher practices bring changes to the conceptualization and application of pedagogical interventions. A design approach into teaching has been proposed for mapping technology with pedagogy to effectively integrate these changes (Laurillard, 2013; Goodyear, 2015; Kali, McKenney, \& Sagy, 2015; Persico, Pozzi, \& Goodyear, 2018). When teachers act as designers of Technology Enhanced Learning (TEL), they engage in reflective, critical and epistemic practices which are beneficial for their life-long learning (Persico, Pozzi, \& Goodyear, 2018). This also contributes to technology sustainability (Cober, Tan, Slotta, So, \& Könings, 2015) and teachers' feelings of ownership (Kali, McKenney, \& Sagy, 2015). Typically, teachers design processes include redesign of existing activities, collaborative design (e.g., in schools, teacher education programs) and evidence-based adaptations (Kali, McKenney, \& Sagy, 2015; Khlaif, Gok, \& Kouraïchi, 2019). Such changes in teacher culture, which has been often described as isiolanist, include the development of professional learning communities which encourage sharing, reflection, and deprivatization of teacher practice (Dana \& YendolHoppey, 2014). The shifting from individual to collective teacher practices has been recently acknowledged in research for the co-construction of teaching ideas and deliberate reflection on teacher design thinking (Tseng \& Kuo, 2014; Hong, Lin, Chai, Hung, \& Zhang, 2019).

Teachers' decisions about their teaching and learning strategies usually rely on previous experiences with students, beliefs on teaching and learning and practical constraints (Matuk, Linn, \& Eylon, 2015). Thus, the use of student-generated data in TEL activities can be valuable to teachers for the adaptations of their instructions and an inquiry into their students' learning (Mor, Ferguson, \& Wasson, 2015). In this context, a growing number of research studies focus on the use of Learning Analytics (LA) for "understanding and 
optimizing learning and the environments in which it occurs" (Ferguson, 2012). Besides, a connection with the pedagogical design of teachers' interventions has been proposed so that LA inform meaningful pedagogical actions and enable teacher inquiry processes (Rienties \& Toetenel, 2016; Rodríguez-Triana, Martínez-Monés, Asensio-Pérez, \& Dimitriadis, 2015; Alhadad \& Thomson, 2017; Percico \& Pozzi, 2015). Such data-intensive methods can consider researcher-practitioner collaborations in authentic settings (e.g., schools, universities) to inform both research and practice (Krumm, Means, \& Bienkowski, 2018).

However, there is still a lack of understanding on how teachers engage in TEL design with the use of LA. Design approaches enable the sharing of teacher ideas and bring opportunities for knowledge exchange in professional teacher communities, but they are still scarce in LA research (Wise, Vytasek, Hausknecht, \& Zhao, 2016). Additionally, participatory approaches in learning design by means of learning analytics are also uncommon (Hernández-Leo, Martinez-Maldonado, Pardo, Muñoz-Cristóbal, \& Rodríguez-Triana, 2018; Voogt, Laferrière, Breuleux, Itow, Hickey, \& McKenney, 2015; McCoy \& Shih, 2016; Cober et al., 2015; Van Gasse, Vanlommel, Vanhoof, \& Van Petegem, 2017). In this paper, we look into teachers' practices in authentic settings and argue that a design inquiry approach with the active participation of teachers is relevant for the meaningful use of learning analytics in teaching and learning. Delving into the learning design and teacher inquiry fields we pose the question on how to support collective inquiry for learning design through data analytics in which teachers and learners are the primary agents of innovative and transformative practices.

The field of learning design or "design for learning" studies how teachers prepare and revise a set of learning activities based on pedagogically-sound decisions which make effective use of resources and technologies (Conole, 2013; Dalziel et al., 2016; Mor, Craft, \& Hernández-Leo, 2013, Beetham \& Sharpe, 2013). The role of teachers as designers implies the meaningful use of tools with the aim to create "the best possible" opportunities for their students to learn (Laurillard, 2012, Kali, McKenney, \& Sagy, 2015). Although teachers design practice e.g., preparation for classroom learning activities, is often considered as an individual task of the teacher, the work of teachers in small groups or larger educational communities is still underexplored (Asensio-Pérez et al., 2017, Agostinho, Lockyer, \& Bennett, 2018, Michos \& Hernández-Leo, 2018, Voogt et al., 2015).

Teachers design and inquiry practice are usually shaped by their work environment and their socio-cultural system. This is situated in the context of their educational institution e.g., schools (Butler \& Schnellert, 2012), universities (Agostinho, Lockyer, \& Bennett, 2018) and their classrooms. Several authors propose collaborative approaches for teachers, especially in Professional Learning Communities (PLCs) (Vescio, Ross, \& Adams, 2008). Mor, Ferguson, \& Wasson (2015) highlight the need to move from individual to collective practices where multiple inquiries about similar learning designs are aggregated. Moreover, Conole (2010) explains the notion of "openness" in teaching and learning. "Open design" addresses the need to move beyond open educational resources and focus on the explicit representation and sharing of the whole design process. Lastly, "open evaluation" refers to the use of data collected from students to collectively improve the teaching practice. These participatory cultures can be formed within groups of teachers in the same educational institutions and through the collaboration between different institutions (Binkhorst, Handelzalts, Poortman, \& van Joolingen, 2015; Hofman \& Dijkstra, 2010). 
Considering the current focus on design approaches to teaching, collective practices for Teacher Professional Development (TPD), we have identified limited frameworks which can support collective teacher inquiry for building (pedagogical) knowledge for learning design. To address this, we propose a framework for studying and supporting teachers as designers in inquiry communities with technologies. We show the implementation of the framework in practice and three cases studies of educational communities in authentic settings; two High schools and a professional teacher community in a Massive Open Online Course (MOOC). In all cases, the community members used an online platform for learning design called Integrated Learning Design Environment-ILDE (Hernández-Leo et al., 2018a).

The structure of the papers is as follows: Section 2 describes relevant theories for collective inquiry and the use of teaching and learning analytics tools for collective teacher inquiry, Section 3 describes our proposed framework while section 4 our methodology. In Section 5, we present data analysis from the three case studies and the implementation of our framework. Section 6 presents a cross-case analysis and results of the three cases and in Section 7 we conclude on how our analysis informed the articulation of the framework.

\section{Relevant theories and tools}

\subsection{Collective inquiry supported by technologies}

The engagement of teachers in goal-directed inquiry into and reflection on practice is a prominent strategy for TPD (Moon, 1999). This creates opportunities for experimentation of new teaching strategies which are situated in everyday classroom and lead to practice development. Collaborative approaches into TPD show that teacher agency can be distributed within a community of teachers to lead to educational change (Butler, Schnellert, \& MacNeil, 2015). Different collective inquiry frameworks have been proposed in two similar areas; in workplace informal learning and teacher learning (Littlejohn \& Hood, 2017). These frameworks show how individual and collective processes supported by technology can be used for knowledge building in a given domain.

The co-evolution model of individual and collective knowledge (Kimmerle, Cress, \& Held, 2010) shows the connection of individuals to the community through knowledge artifacts when using ICT such as wikis. Individuals externalize their knowledge through knowledge artifacts like chat log files, wiki articles or weblog entries and other community members internalize them in a process of collective knowledge. In the workplace context, Littlejohn, Milligan, \& Margaryan (2012) explain the interrelation of self-regulated learning and collective knowledge. They propose a model in which individuals consume, connect and contribute to collective knowledge while interacting with Web 2.0 technologies, other people and by using ICT tools to reflect and achieve their own goals. Ley et al (2014) articulate a model for informal workplace learning at scale. Their model includes the individual process to perform and reflect on a workplace task, the social support provided through social networking, the emergence, and generation of collective knowledge. This has been further proposed with the use of technologies which include community, semantic and mobile services.

In the context of teachers, several researchers study online teacher communities as Communities of Practice (CoPs) (Wegner,1998) or Professional Learning Communities (PLCs) (Vescio, Ross, \& Adams, 2008). In CoPs, collective learning processes emerge when members, e.g., teachers, work together in a joint 
enterprise, use shared knowledge and a shared repertoire (tools, objects, artifacts, rules). Research in PLCs acknowledges that active teachers' participation and collaborative activities have an impact in teaching practice (Berry, Johnson, Montgomery, 2005) and students' learning (Bolam et al., 2005). Recently, many scholars study knowledge building processes (Scardamalia and Bereiter, 2003) within such professional teacher communities (Popp \& Goldman, 2016). Characteristics of knowledge building applied to teacher communities include the collaborative community efforts, the improvable ideas proposed by members and the added value in the community such as authentic practical questions and solutions to problems. Laurillard, Kennedy, Charlton, Wild, \& Dimakopoulos (2018) explain the development of a learning design tool for teachers (Learning Designer) which aims to build pedagogical-knowledge building communities where teachers can work as designers by sharing instructional products, their classroom inquiry and build on each other contributions. Such online community spaces for teachers enable the sharing of teaching knowledge and the integration of technological, pedagogical and content knowledge (TPACK) (Koehler, \& Mishra, 2009).

Another well-known collective inquiry framework is that of Community of Inquiry (CoI) (Garrison, \& Arbaugh, 2007) which has been often applied into student learning and in some cases into pre-service teacher learning (Yang, 2016). The framework shows the interconnection of the social, cognitive and teaching presence to study online communities. The cognitive presence describes learning as a Practical Inquiry (Garrison, Anderson, \& Archer, 2001) which leads to knowledge construction and problem solution. The social presence shows the interaction between community members to achieve learning outcomes. The teaching presence shows the role of teachers to design and implement courses which include social and cognitive processes. Some applications of the framework include online learning with Learning Management Systems (LMS) or with Massive Open Online Learning (MOOC) platforms (Kovanović, Gašević, Joksimović, Hatala, \& Adesope, 2015).

The above presented learning theories in workplace settings; self-regulated learning and collective knowledge (Littlejohn, Milligan, \& Margaryan, 2012), workplace learning at scale (Ley et al, 2014), and co-evolution model of individual and collective knowledge (Kimmerle, Cress, \& Held, 2010), explain the meaningful use of technologies for collective inquiry but there is no framework in the context of TPD or the teachers as designers field. Moreover, the above teacher communities' frameworks do not integrate the use of technologies and analytics tools by teachers in relation to knowledge building. Although the CoI framework has been often used in the context of computer-mediated student learning few examples address teacher learning and TPD (Yang, 2016; Papanikolaou, Makri, \& Roussos, 2017). In these cases, the CoI model was essentially explored with pre-service teachers through collaborative structures, collective, peer feedback and types of knowledge building. In this paper, we draw on common elements of the above frameworks and articulate a collective inquiry framework for teachers as designers in pre-service and inservice teacher education. The elements show how individual and collective processes can be integrated with technologies (the interrelation of self-regulated learning and collective knowledge, knowledge building processes in teacher communities, the social and cognitive presence in $\mathrm{Col}$ ). Next section presents analytics tools in TPD and their connection with collective teacher inquiry.

\subsection{The use of teaching and learning analytics tools for collective teacher inquiry}

One collective approach for TPD is the engagement of teachers in collaborative inquiry through data teams. In this model, teachers discuss and interpret together student data about their classrooms rather than 
working alone (Mandinach, \& Jimerson, 2016; Van Gasse et al., 2017). Recent TPD programs introduce the use of Learning Analytics (LA) systems for teachers or Teaching Analytics (TA) tools with the aim to use and adopt such technologies in everyday teaching (Michos, Hernández-Leo, \& Albó, 2018; Rienties, Herodotou, Olney, Schencks, \& Boroowa, 2018).

LA are defined as "the measurement, collection, analysis, and reporting of data about learners and their contexts, for purposes of understanding and optimizing learning and the environments in which it occurs" (Ferguson, 2012). Moreover, the subfield of TA focuses on the design, development, and evaluation of visual analytics methods and tools for teachers, to understand teaching and learning (Vatrapu, Teplovs, Fujita, \& Bull, 2011; Prieto, Sharma., Dillenbourg \& Rodríguez-Triana, 2016). One argument is that the connection between Teaching and Learning Analytics (TLA) can provide insights and improve teacher inquiry practice (Sergis \& Sampson, 2017).

Teacher inquiry is a strategy for teacher professional development which includes the examination of teachers' own and peer practices (Mor, Ferguson, \& Wasson, 2015). Teacher inquiry involves classroom teachers in a cycle of inquiry, reflection, and action related to problems and evidence-based solutions for classroom teaching (Clarke \& Erickson, 2003). Luckin, Clark, Avramides, Hunter, and Oliver (2017) conduct a literature review for teacher inquiry and show its connection with teacher design research. They argue that teacher design research is a participatory design approach to "develop teachers' expertise as adaptive innovators through long-term involvement in iterative design research and a process of guided professional development". This approach considers teachers rather than researchers as the starting point in the design process and their involvement in a shared community of inquiry (Cochran-Smith, \& Lytle, 2009; Bannan-Ritland, 2008; Laurillard, 2012; Kali, Eylon, McKenney, \& Kidron, 2018) contributes to their own learning and professional development.

Considering recent developments on learning and teaching analytics tools and their connection with teacher inquiry, we identify limited frameworks which show how such participatory design approaches for teachers as designers can be studied and supported with technology. In the following section, we formulate our framework to address this gap.

\section{Collective Inquiry with Data Analytics (CIDA): A framework for collectively supporting teachers' design practice with data analytics.}

Based on two recent studies in teacher communities (Michos \& Hernández-Leo, 2018; Michos, HernándezLeo, \& Albo, 2018), we articulate the Collective Inquiry with Data Analytics (CIDA) framework (see Figure 1). Our theoretical underpinning is based on teacher professional development and teacher learning and uses the Cultural Historical Activity Theory (CHAT) (Engestrom, 2000) and Teacher Inquiry cycle (Clarke \& Erickson, 2003) to describe the meaningful use of data analytics for supporting teachers' design work. Data analytics in this context can inform teachers when designing and implementing learning scenarios (Hernández-Leo et al., 2018b) and generate practical and theoretical knowledge within teacher communities. The framework is proposed as a participatory approach for studying and supporting teacher communities which utilize technology and data analytics and involve their community members as codesign participants, e.g. other teachers and their students. The articulation of the framework targets: a) 
researchers who study teacher design practices and data use by teachers, b) educational practitioners such as teachers and, c) system developers who work with learning and teaching analytics tools for teachers.

Based on our literature review about collective inquiry frameworks for knowledge building and teaching and learning analytics for teacher inquiry, we identify three interconnected components to support teachers as designers within inquiry communities. The three components are a) the inquiry process, b) the collective process and, c) technological support. The relationships between the three components show how collective teacher inquiry can be enhanced with technologies and data analytics and how it contributes to TPD.

\section{Inquiry process}

The inquiry process component includes the work of teachers in goal-directed inquiry and reflection on their practice. Teacher inquiry is considered as a cyclic, self-regulating process to design and implement learning scenarios with the use of teaching and learning analytics. It involves teachers in a cycle of problem definition, design, implementation, and data-informed reflection. The aim is the meaningful connection between pedagogical intentions and teachers' practical questions with the collection of learning analytics during the enactment of learning designs. In Michos, Hernández-Leo \& Albó (2018) we show empirical evidence on how teacher inquiry supported by a web-based tool was implemented in practice with school teachers and enabled data-informed teacher reflections. Teachers involvement in inquiry cycles showed evidence of knowledge building regarding the design and enactment of learning activities.

\section{Collective Process}

The collective process component shows that the social environment shapes and guides teacher practices. Considering that teacher development and learning is informed by their socio-cultural educational system and includes the use of resources (e.g. peers, students, head teachers, professional workshops, teacher artifacts) (Agostinho, Lockyer, \& Bennett, 2018; Butler \& Schnellert, 2012), the framework shows how teacher inquiry is informed by a community of teachers and learners through mediating artifacts (e.g. mediated by learning design methodologies and tools, teacher artifacts, community). In this context, CHAT describes the purposeful activity of teacher inquiry to create and implement learning designs through mediating artifacts (subjects-teachers, mediating artifacts-learning design methodologies and tools, objectcreating and implementing learning designs) and aligns with the teacher inquiry cycle. Additionally, this object-oriented activity is informed by the community of teachers and learners, the rules or constraints of their educational institution and the different roles of the community members. In Michos \& HernándezLeo (2018) we show how we used the CHAT framework and data analytics to provide community awareness in a web-based teacher community about their peers, the use of learning design tools and teacher artifacts and how data-informed community reflections can assist teachers.

\section{Technological support}

The technological support component includes the use of technology for collective teacher inquiry. To enable the use of data analytics, the technology used by teachers is an integral part of the framework. For instance, community-oriented platforms which provide spaces for sharing learning designs can provide technological support for community inquiry within teacher communities. In this context, community awareness with data analytics can inform and inspire teachers' design inquiry (Michos \& Hernández-Leo, 2018). Moreover, when teachers enact technology-enhanced learning scenarios, the use of learner data and 
learning analytics can inform further teachers' designs and contributes to collective inquiry (Michos, Hernández-Leo \& Albó, 2018)

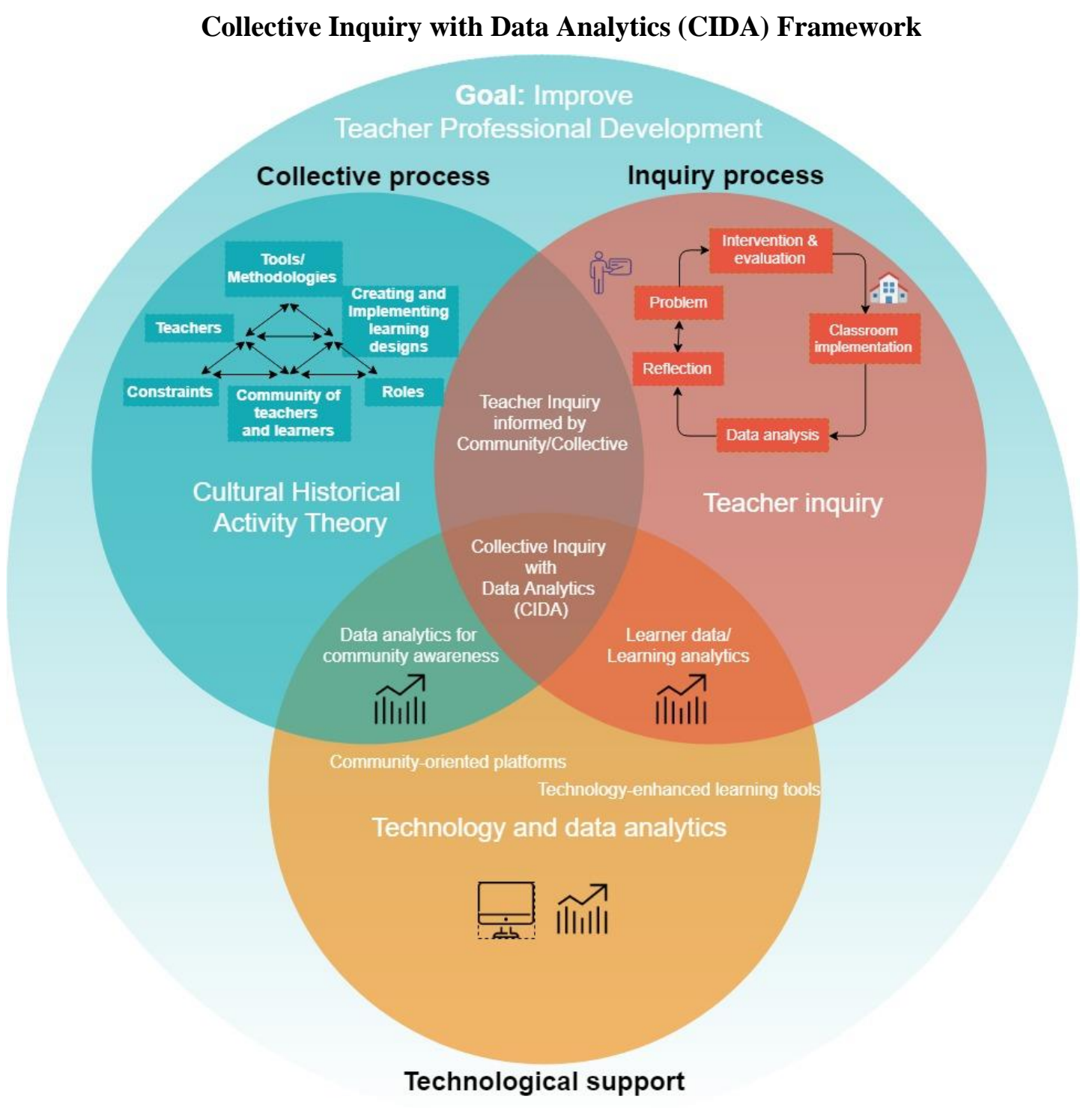

Figure 1. The CIDA framework for collectively supporting teachers' design practice with data analytics.

\section{Relationships between the three components}

The relationship between the inquiry and collective process shows how teacher inquiry is informed by the community of teachers and learners based on the CHAT elements. Both CHAT and teacher inquiry describe a purposeful teacher activity to develop and implement learning designs. The relationship between the inquiry process and technological support show how learner data or learning analytics collected during the enactment of TEL scenarios can enhance teacher reflection and inquiry. Additionally, the relationship between the collective process and technological support shows how community awareness data related to 
CHAT elements (teachers, learning design tools, learning designs artifacts) can enhance collective reflection and inquiry. The relationship between the three components (collective, inquiry process and technological support) shows how Collective Inquiry with Data Analytics (CIDA) contributes to teacher professional development. Through this data-informed collective process teachers develop practical and theoretical knowledge (e.g., types of technological, pedagogical, and content knowledge) (Koehler, \& Mishra, 2009).

To evaluate the above framework, we formulated the following research questions:

- RQ1: Does the framework help to study and support participatory teacher design practice enhanced with data analytics?

- RQ2: How does the framework help to study and support participatory teacher design practice enhanced with data analytics?

- RQ2a: How do teachers engage with data-informed collective inquiry processes?

○Q2b: How do teachers perceive data-informed collective inquiry processes?

\section{Methodology}

This research work is part of an overall Design-Based Research (DBR) methodology (Amiel \& Rieves, 2006) which aims to develop data analytics support for teachers as designers in technological environments. In Michos \& Hernández-Leo (2018), we explain the suitability of this methodology to understand and support teacher practice by conducting research in authentic environments (e.g., schools). The framework was developed after completing two DBR cycles with teachers (Michos \& Hernández-Leo, 2018; Michos, Hernández-Leo, Albó, 2018). In this paper, we use a case study methodology (Yin, 2009) to describe, inform and validate the articulation of our framework. We chose three representative authentic settings for teachers; two communities of High school teachers and a professional teacher community in a Massive Open Online Course (MOOC). The three analyzed teacher communities participated in a Professional Development (PD) program about learning design. The three communities differed in the pre-existing relationships of their members and the time duration of the received PD program which have been acknowledged as key factors for participation and TPD in online teacher communities (Lantz-Andersson, Lundin \& Selwyn, 2018; Macià \& García, 2016; Michos \& Hernández-Leo, 2018). In schools, teachers participated in a two-year PD program and knew each other whereas, in the MOOC, the participating teachers followed the PD course for 6 weeks and had no previous relationships.

\subsection{Integrated Learning Design Environment (ILDE)}

To enable the inquiry and collective process to emerge, community platforms for exchanging learning designs are example technologies for collective teacher inquiry. For instance, the platforms LAMS (Dalziel, 2016) and Learning Designer (Laurillard et al., 2018) support the creation and sharing of learning designs. In our case, we used ILDE, another community platform which facilitates the full-lifecycle of learning design, from the conceptualization of learning activities until their implementation in Virtual Learning Environments-VLEs (Hernández-Leo et al., 2018). ILDE members can create learning designs with a variety of tools and share, re-use and comment designs created by other members (Figure 2). The ILDE was used in the school communities and the MOOC community. 


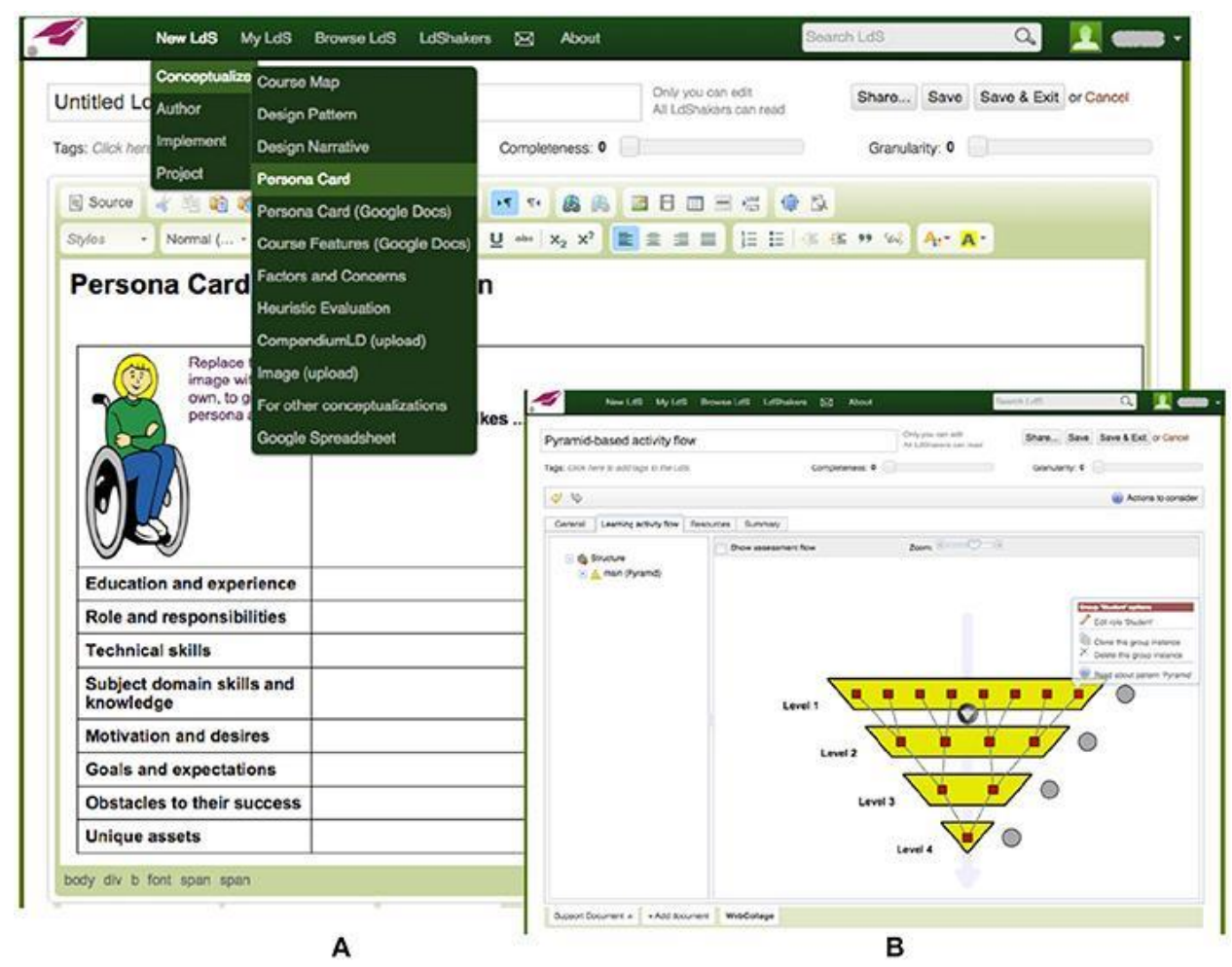

Figure 2. Integrated Learning Design Environment (ILDE) showing different learning design tools for conceptualization (A) and authoring (B) of learning designs (Hernández Leo et al., 2018, p.10).

\subsection{Description of the inquiry community cases}

\subsubsection{School communities (two schools)}

$N=33$ teachers participated in a two-year Professional Development (PD) program. The objectives of the PD program were twofold: a) teacher training in technology-supported learning design, and b) teacher training in the meaningful use of student-generated data in technology-integrating activities. The program occurred during a research project which was formed between a university research group and two High Schools. The primary learning design methodology of the program was the design of Collaborative Learning (CL) (Johnson \& Johnson, 1994). $N=14$ teachers out of 33 volunteered to implement their learning designs in their classrooms and completed a whole inquiry cycle with the collection and interpretation of student data.

\subsubsection{Community in a Massive Open Online Course for teachers}

$N=209$ teachers registered into ILDE during the MOOC "Innovative Collaborative Learning with ICT". The MOOC targeted teachers and the main objective was the design and implementation of collaborative learning activities with technologies. The participating teachers were teaching various subjects in different educational levels (from primary education to higher education). $N=100$ teachers created at least one learning design artifact which included either a conceptualization of a collaborative learning scenario or a detailed lesson plan. In this case, teachers did not implement their learning designs because the MOOC was running between June-July 2017 and there were limited opportunities to implement them with students. 


\subsection{Professional development activities}

Two schools participated in the PD program and received training in the form of 2-hour monthly workshops. The teachers were using the learning design platform ILDE (Hernández-Leo et al., 2018) to design, implement and share their inquiries. In the MOOC community, teachers were asked to perform different online activities with ILDE every week and were provided with instructions in the Canvas MOOC platform. Table 1 shows the description and duration of the PD activities in the three community cases.

Table 1. Professional development activities in the participating communities

\begin{tabular}{|c|c|c|c|}
\hline Time period & $\begin{array}{l}\text { Communities of school } \\
\text { teachers }\end{array}$ & Time period & $\begin{array}{l}\text { Community in a MOOC for } \\
\text { teachers }\end{array}$ \\
\hline 2 times $x 2$ hours & $\begin{array}{l}\text { Workshop: Initial exploration } \\
\text { of learning design tools }\end{array}$ & 1 week & $\begin{array}{l}\text { Design of collaborative } \\
\text { learning: theory and practices }\end{array}$ \\
\hline 1 month & $\begin{array}{l}\text { Online activity: documentation } \\
\text { of teaching-learning activity } \\
\text { sequences }\end{array}$ & 1 week & $\begin{array}{l}\text { ICT collaborative tools for } \\
\text { teachers and students }\end{array}$ \\
\hline 4 times $x 2$ hours & Workshop: Design of CL & 1 week & $\begin{array}{l}\text { Design and implementation of } \\
\text { CL activities based on Pyramid } \\
\text { pattern. }\end{array}$ \\
\hline $\begin{array}{l}2 \text { times } x 2 \\
\text { months }\end{array}$ & $\begin{array}{l}\text { Implementations: Classroom } \\
\text { implementations with } \\
\text { technology-enhanced learning } \\
\text { tools }\end{array}$ & 1 week & $\begin{array}{l}\text { Design and implementation of } \\
\text { CL activities based on Jigsaw } \\
\text { pattern. }\end{array}$ \\
\hline 4 times $x 2$ hours & $\begin{array}{l}\text { Workshop: Joint teachers' } \\
\text { reflections on learning } \\
\text { analytics }\end{array}$ & 1 week & $\begin{array}{l}\text { Learning Design project and } \\
\text { peer reflection }\end{array}$ \\
\hline
\end{tabular}

\subsection{Instruments and data collection methods}

Throughout the PD programs, we used a mixed method approach with collection and triangulation of quantitative and qualitative data (Creswell \& Plano Clark, 2007) to evaluate our research questions. The main data sources were the following:

- Log data (Quantitative). Teachers actions and interactions's with the ILDE online learning design platform.

- Online comments (Qualitative). Teachers' comments about learning design artifacts in ILDE.

- Teacher artifacts (Qualitative). Teachers’ produced artifacts with ILDE tools.

- Questionnaires (Quantitative, Qualitative). One questionnaire about perceived usefulness of a community awareness dashboard based on CHAT (see Appendix Table A.1, Cronbach's alpha = .74). One questionnaire about perceived usefulness of different ILDE tools after the completion of the MOOC (see Table A.7, Cronbach's alpha $=.85$ )

- Interviews (Qualitative). 7 semi-structured face-to-face interviews with the teachers who implemented learning designs in schools (see Tables A.2-A.3). Teachers who did not implement their designs responded to the same interview questions with a questionnaire. 
The development of the research instruments and the data analysis was driven by the proposed CIDA framework (collective, inquiry process and technological support). Moreover, we used the TPACK framework to report results about types of technological, pedagogical, content knowledge activated during teachers'online interactions (Koehler, \& Mishra, 2009; Boschman, McKenney, \& Voogt 2015) and to show the impact of the interrelations between the three CIDA components. Two researchers familiarized with the data and coded the entire online comments as the unit of analysis. The process was iteratively done until reaching an inter-rater agreement between the coders. Log data were analyzed in Tableau ${ }^{1}$ with the aim to understand teachers' online participation and interactions. Teachers' interviews, open responses in questionnaires and teacher artifacts were analyzed with inductive thematic analysis driven by our research questions. An open coding scheme was used to report the results of the thematic analysis. Quantitative data from questionnaires were analyzed in IBM SPSS 22.

In Table 2 we show how the above data were used to answer our RQs based on our proposed framework.

Table 2. Data collection methods based on the framework and the Research Questions

\begin{tabular}{|c|c|c|c|c|}
\hline \multirow{3}{*}{\multicolumn{2}{|c|}{ CIDA framework }} & \multirow[t]{3}{*}{ Cases } & \multirow{2}{*}{\multicolumn{2}{|c|}{$\begin{array}{l}\text { RQ1: Does the framework help to study and support } \\
\text { participatory teacher design practice enhanced with data } \\
\text { analytics? } \\
\text { RQ2: How does the framework help to study and support } \\
\text { participatory teacher design practice enhanced with data } \\
\text { analytics? }\end{array}$}} \\
\hline & & & & \\
\hline & & & $\begin{array}{l}\text { RQ2a: How do teachers } \\
\text { engage with data-informed } \\
\text { collective inquiry processes? }\end{array}$ & $\begin{array}{l}\text { RQ2b: How do teachers } \\
\text { perceive data-informed } \\
\text { collective inquiry processes? }\end{array}$ \\
\hline & $\begin{array}{l}\text { Technological } \\
\text { Support } \\
\text { (see Section 5) }\end{array}$ & & & \\
\hline $\begin{array}{l}\text { Collective } \\
\text { Process }\end{array}$ & $\begin{array}{l}\text { ILDE, } \\
\text { inILDE, } \\
\text { TILE }\end{array}$ & $\begin{array}{l}\text { School } \\
\text { communities } \\
\text { (two schools) }\end{array}$ & Log data, Online Comments & Interviews \\
\hline & $\begin{array}{l}\text { ILDE, } \\
\text { inILDE }\end{array}$ & MOOC & Log data, Online Comments & $\begin{array}{l}\text { Questionnaires (Open and } \\
\text { closed questions) }\end{array}$ \\
\hline $\begin{array}{l}\text { Inquiry } \\
\text { Process }\end{array}$ & $\begin{array}{l}\text { ILDE, } \\
\text { inILDE, } \\
\text { TILE }\end{array}$ & $\begin{array}{l}\text { School } \\
\text { communities } \\
\text { (two schools) }\end{array}$ & $\begin{array}{l}\text { Log data, Teacher artifacts } \\
\text { TILE }\end{array}$ & Interviews \\
\hline & ILDE, inILDE & MOOC & $\begin{array}{l}\text { Log data, Teacher artifacts in } \\
\text { ILDE }\end{array}$ & $\begin{array}{l}\text { Questionnaire (Open and } \\
\text { closed questions) }\end{array}$ \\
\hline
\end{tabular}

\section{Data analysis}

\footnotetext{
${ }^{1}$ https://www.tableau.com/
} 
In the following sections, we present data analysis from the three case studies. We describe how the framework was implemented in practice based on the three components: a) technological support b) collective process, c) inquiry process and their relationships.

\subsection{Technological support}

In this section, we describe examples of technologies co-designed with teachers contributing to the technological support component and its relationship with the collective and inquiry process components of our framework.

\subsubsection{Community analytics dashboard: inILDE}

Towards supporting the collective process by means of data analytics, we developed a community awareness dashboard (inILDE) for online teacher communities. inILDE is a mirroring tool which displays the actions performed by teachers in the ILDE environment and aims to provide social awareness for community regulation and reflection (Figure 3). The tool is implemented as a dashboard and includes data visualizations regarding: a) participation analytics of community members, b) usage analytics for different learning design tools, and c) usage analytics about learning design artifacts. In Michos \& Hernández-Leo (2018) we explain the design and study of the community dashboard based on the CHAT framework. The community dashboard was used in the school communities and the MOOC community.

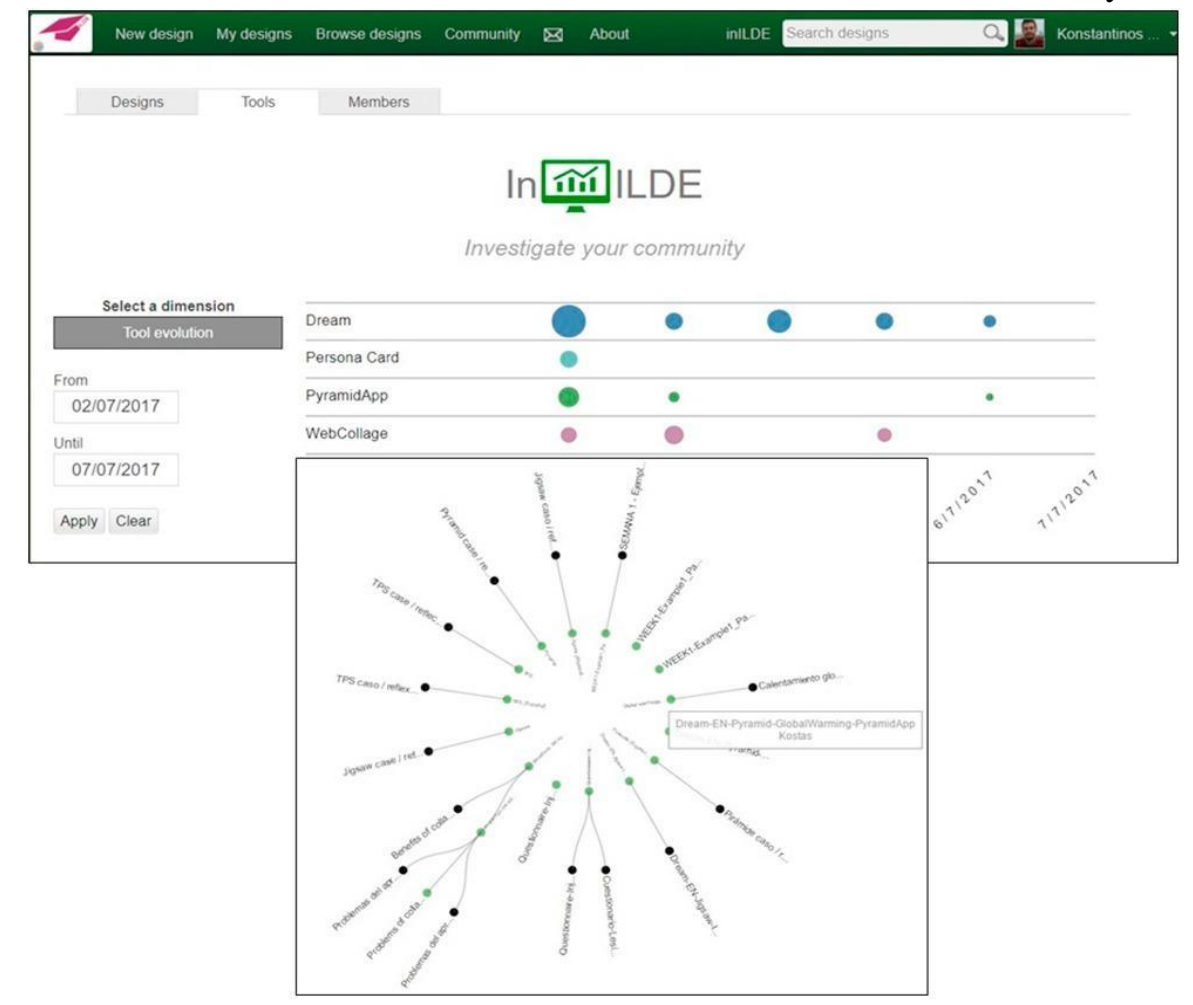

Figure 3. Community analytics dashboard (inILDE) showing usage analytics of different learning design tools (above) and radial tidy tree with reused learning design artifacts (below) within a teacher community (Michos \& Hernández-Leo, 2018).

\subsubsection{Teacher-led Inquiry for Learning dEsigns (TILE)}


Considering the inquiry process and technological support, we developed a tool which helps and guides teachers to conduct an inquiry into classroom activities with technologies. TILE is a web-based interactive tool for teachers and educational designers which sequences the Teacher Inquiry cycle in 4 Steps: 1) the identification of problems and inquiry questions, 2) the design of the intervention with a data collection plan, 3) the analysis of the collected data after the implementation, and 4) the reflection on the implementation. The tool is embedded in learning design tools within the ILDE and aims to scaffold systematic teacher inquiry with the collection and interpretation of learning analytics (Figure 4). After the completion of inquiry cycles, teachers can share and comment on their documented inquiries. The TILE tool was used only in the school communities (Michos, Hernández-Leo, Albó, 2018) because teachers were able to implement their designs with students in classrooms.

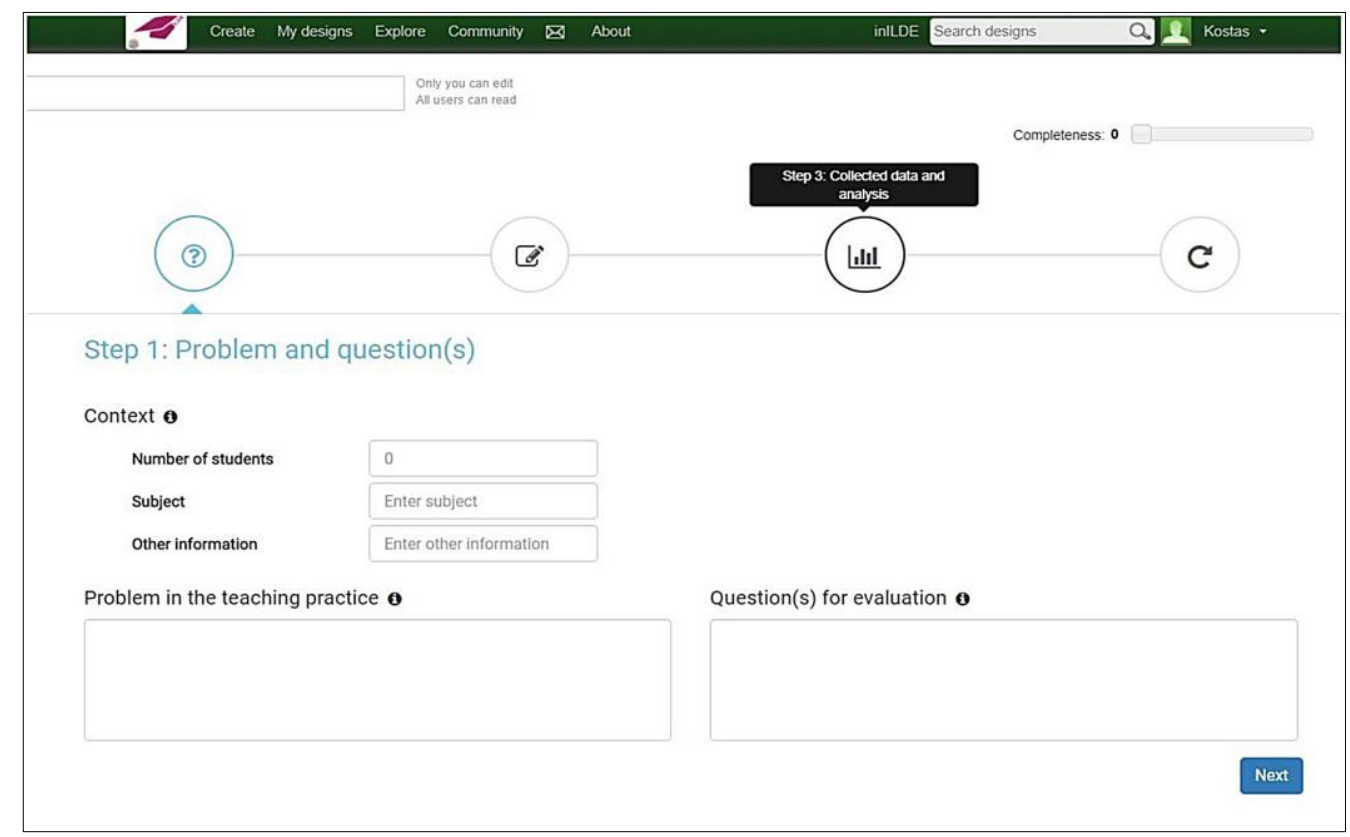

Figure 4. Teacher-led Inquiry for Learning Designs (TILE) tool integrated into ILDE showing the first step of the teacher inquiry process about problem and question formulation (Michos, Hernández-Leo, \& Albó, 2018).

In the MOOC, we facilitated the teacher inquiry process with the tools provided in ILDE (conceptualization, authoring and deployment tools) and the Canvas MOOC platform. In this case, teachers created and commented artifacts which included detailed conceptualizations and descriptions of collaborative learning activities.

\subsection{Teacher engagement with CIDA (collective, inquiry process and technological support)}

\subsubsection{School communities}

We present analysis related to teacher engagement in the three components of the framework. Following the inquiry process of the CIDA, school teachers were involved in cycles of design, implementation, and reflection with the TILE tool. Out of 33 teachers who participated in the PD program, 14 implemented CL activities with technology and documented a complete inquiry cycle (see Figure 4). Teachers also used the 
PyramidApp tool (Manathunga \& Hernández-Leo, 2018) to design and implement their collaborative activities. PyramidApp supports the design and implementation of collaborative learning activities based on the Pyramid pattern. In this case, the collaborative activity starts from an individual phase, then students formulate small groups and later larger groups until reaching consensus in a given topic. A total of $N=508$ High school students participated in classroom activities in the two schools.

Following the collective process of CIDA, teachers were provided with the learning design, a documented inquiry cycle and student data of an implemented classroom activity (see Figure A.1 in the Appendix) and were asked to jointly reflect with comments in ILDE. To report the impact of involving teachers in datainformed collective inquiry processes, we used the TPACK framework. The analysis aimed to identify what types of TPACK knowledge teachers activate while reflecting on others' data-informed inquiry cycles and what is the added value of the three CIDA components (collective process, inquiry process, and technological support). We performed a content analysis of teachers' comments in two tasks for peer reflections. We coded their comments based on TPACK with the entire comment as units of analysis (Table $3)$.

Table 3. Analysis of group reflections based on TPACK in two data-informed reflective tasks in the schools.

\begin{tabular}{|c|c|c|}
\hline Code & Meaning & Excerpt \\
\hline TK & $\begin{array}{l}\text { Use of computers without referencing to } \\
\text { learning or teaching }\end{array}$ & $\begin{array}{l}\text { "We have reached similar conclusions regarding } \\
\text { the use of the tool." }\end{array}$ \\
\hline PK & $\begin{array}{l}\text { General teaching and learning strategies or } \\
\text { learning activities. }\end{array}$ & $\begin{array}{l}\text { "The activity seems suitable for learning. The } \\
\text { students show satisfaction for the learning and the } \\
\text { methodology used." }\end{array}$ \\
\hline CK & Subject-matter regarding discussions. & $\begin{array}{l}\text { "The discussions between the group members are } \\
\text { in the form of chat, with incomplete and little- } \\
\text { argued answers." }\end{array}$ \\
\hline TPk & $\begin{array}{l}\text { Use of computers related to teaching/learning } \\
\text { and classroom practice. }\end{array}$ & $\begin{array}{l}\text { "The activity is very good in favoring the } \\
\text { participation of all the students in making a } \\
\text { conclusion. However, the data shows that the } \\
\text { number of students' responses is not equal. It may } \\
\text { be due to connection problems, so I think it is very } \\
\text { important to be able to keep pace with what is } \\
\text { happening in class (if they do not respond to } \\
\text { technical problems, connection to the internet or for } \\
\text { lack of ideas) to be able to make an assessment, } \\
\text { which may not show the statistics." }\end{array}$ \\
\hline TCk & $\begin{array}{l}\text { Use of computers to represent subject matter } \\
\text { knowledge. }\end{array}$ & (Not present in teachers' comments) \\
\hline PCk & $\begin{array}{l}\text { Teaching and learning strategies related to } \\
\text { subject matter. }\end{array}$ & $\begin{array}{l}\text { "Students need more guidance on how to ask } \\
\text { questions and answers in a debate. There is a lot of } \\
\text { difference in how they talk about each other as they } \\
\text { write the final answer. I think it's important because } \\
\text { the debate is not enriched." }\end{array}$ \\
\hline TPCk & $\begin{array}{l}\text { Integrated use of computers related to teaching } \\
\text { and learning strategies and content knowledge }\end{array}$ & $\begin{array}{l}\text { "It is an interesting activity. It makes a } \\
\text { comprehension work dynamic and generates debate } \\
\text { among the students. The technology enables the } \\
\text { collection of data that can be reviewed to improve } \\
\text { the activity." }\end{array}$ \\
\hline Other & Social appraisal comments and other feedback. & $\begin{array}{l}\text { "Very good activity, very interesting reflections } \\
\text { arise." }\end{array}$ \\
\hline
\end{tabular}


Out of 91 coded comments, the largest amount of knowledge activated by teachers was pedagogical $(\mathbf{P K}=34 \%)$ referring to teaching or learning strategy after reviewing the teacher and student data of a peer teacher. Then comments coded as Other referred to social appraisal such as rewarding comments and content which did not refer to one of the TPACK categories. This type of comments was the second most common (Other $=28 \%)$. Then followed two types of integrated pedagogical and content knowledge $(\mathbf{P C k}$ $=19 \%)$ and technological and pedagogical knowledge $(\mathbf{T P k}=11 \%)$ while separated technological $(\mathbf{T K}=3 \%)$ or content knowledge $(\mathbf{C K}=3 \%)$ was uncommon in teachers' reflective comments (Figure 5). Thus, the predominance of pedagogical and content knowledge activation shows added value in teachers' peer reflections with the inquiry cycles documentations and the student data.

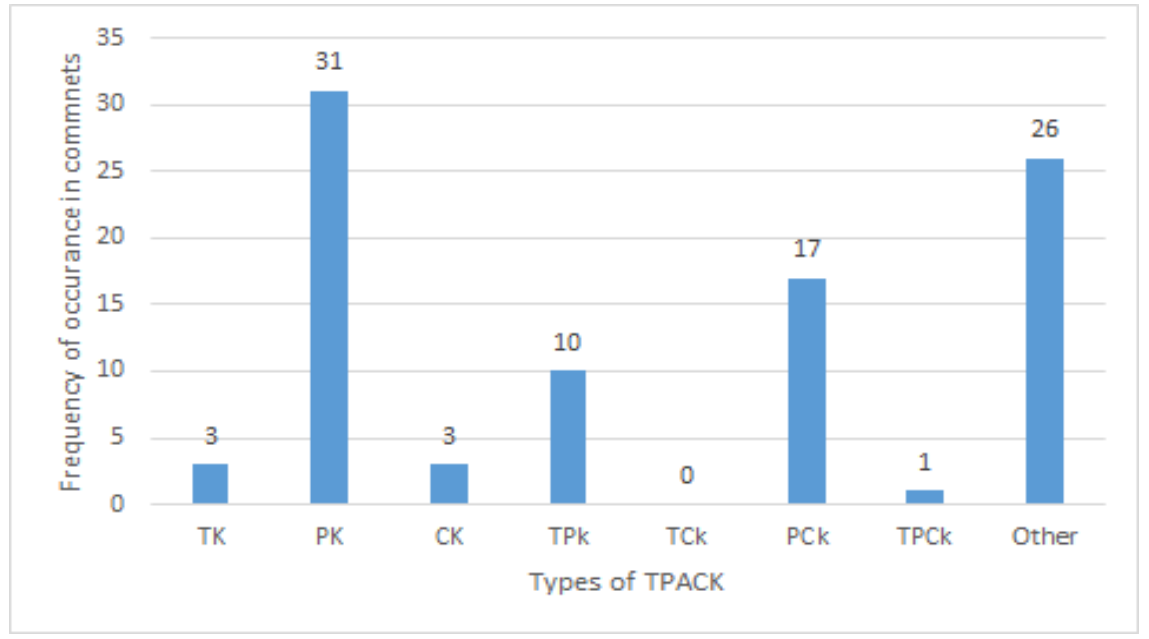

Figure 5. Types of TPACK knowledge activated during the peer-reflection tasks in the schools

Regarding their engagement in the inquiry process, we evaluated the use of the TILE tool with the log data collected from ILDE. Figures 6-7 show frequency of use of the TILE tool in the two schools and timeline per week. In both schools, there were different types of engagement in the inquiry process (from the design to the reflection) according to the available time of teachers and their interest to conduct a classroom inquiry with technologies. Thus, 3-4 teachers were the most active in each school (used TILE more than 10 times) and the rest were involved at a lower level. Figure 6(B) and Figure 7(B) show the time periods in which the tool was used. Teachers initially formulated the problem, questions and data collection plan in December 2018 and reflected on the collected student data in February 2018. This pattern of use is shown in Figure 6(B) and Figure 7(B). In School 2, some teachers conducted a second inquiry cycle and thus more reflections on student data occurred in April 2018. 


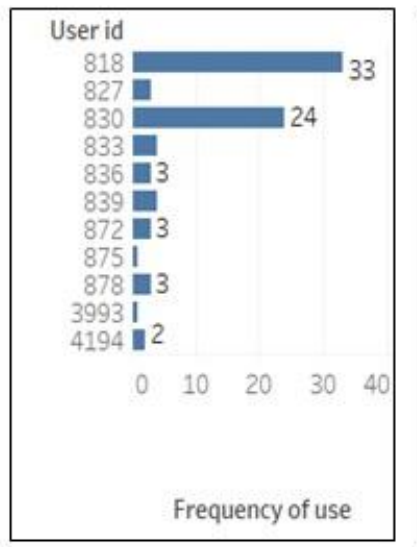

(A)

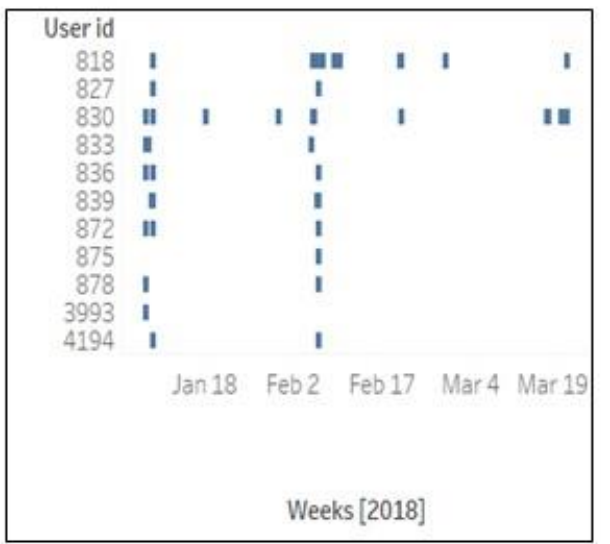

(B)

Figure 6. School 1: Frequency of TILE tool use (A) and timeline of use (B) by teachers

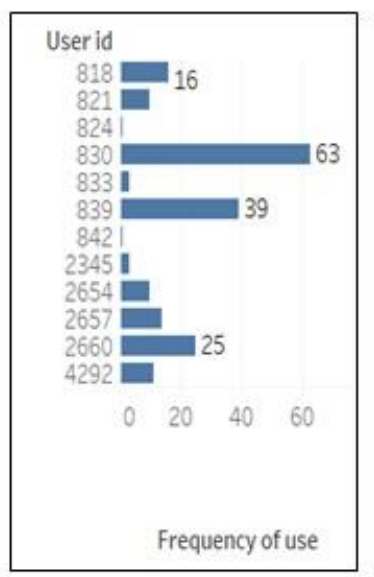

(A)

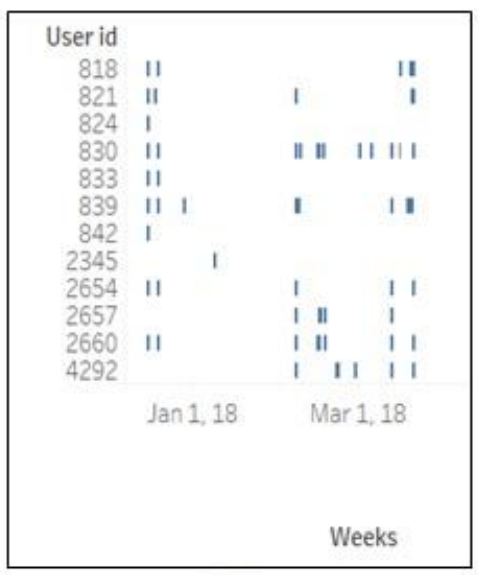

(B)

Figure 7. School 2: Frequency of TILE tool use (A) and timeline of use (B) by teachers

To further understand the teacher inquiry process, we performed a content analysis of the produced teacher artifacts with the TILE tool by extracting the main topics in each inquiry step. The analysis was driven by the teacher inquiry steps of CIDA which was implemented in the TILE tool. We analyzed a sample of four teacher artifacts in School 1 and a sample of six teacher artifacts in School 2 considering the most active teachers (see Table 4-5).

Table 4. School 1: Sample of teachers' inquiries produced by the TILE tool

\begin{tabular}{|l|l|l|l|}
\hline Teacher code* & TS1.a & TS1.b & TS1.c \\
\hline Subject & Economics and Business & Philosophy & $\begin{array}{l}\text { Biology and Earth } \\
\text { Sciences }\end{array}$ \\
\hline Teaching experience & 24 years & 25 years & 20 years \\
\hline
\end{tabular}




\begin{tabular}{|l|l|l|l|}
\hline Problem/Questions & $\begin{array}{l}\text { Collaborative conclusions } \\
\text { from a questionnaire }\end{array}$ & $\begin{array}{l}\text { Brainstorming to define a } \\
\text { concept }\end{array}$ & $\begin{array}{l}\text { Brainstorming to define a } \\
\text { concept }\end{array}$ \\
\hline Intervention / Evaluation & $\begin{array}{l}\text { CL activity about } \\
\text { conclusions in collected } \\
\text { data from students }\end{array}$ & $\begin{array}{l}\text { CL about initial } \\
\text { definitions and final } \\
\text { conclusions }\end{array}$ & $\begin{array}{l}\text { CL about initial } \\
\text { definitions }\end{array}$ \\
\hline Collected student data & $\begin{array}{l}\text { Engagement, content, } \\
\text { observation notes }\end{array}$ & Engagement, content & $\begin{array}{l}\text { Engagement, content, } \\
\text { observation notes }\end{array}$ \\
\hline $\begin{array}{l}\text { Reflections for learning } \\
\text { (re) design }\end{array}$ & $\begin{array}{l}\text { Time management, } \\
\text { off-task discussions, } \\
\text { student understanding, } \\
\text { emerged open student } \\
\text { attitude, } \\
\text { improving instructions } \\
\text { before-during task }\end{array}$ & $\begin{array}{l}\text { Time management, } \\
\text { achieved brainstorming, } \\
\text { management of students' } \\
\text { groups, teacher's } \\
\text { presentation of the task }\end{array}$ & $\begin{array}{l}\text { Time management, } \\
\text { off-task discussions, } \\
\text { control of the tool, } \\
\text { participatory approach, } \\
\text { collecting students'ideas }\end{array}$ \\
\hline
\end{tabular}

${ }^{*}$ TS1 $=$ Teacher in School 2

Table 5. School 2: Sample of teachers' inquiries produced by the TILE tool

\begin{tabular}{|c|c|c|c|c|c|}
\hline Teacher code & TS2.a & TS2.b & TS2.c & TS2.a & TS2.g \\
\hline Subject & $\begin{array}{l}\text { Biology and } \\
\text { Chemistry }\end{array}$ & Earth Sciences & $\begin{array}{l}\text { Maths and } \\
\text { Technology }\end{array}$ & $\begin{array}{l}\text { Biology and } \\
\text { Chemistry }\end{array}$ & Philosophy \\
\hline Teaching experience & 5 years & 14 years & 7 years & 5 years & 25 years \\
\hline Problem/Questions & $\begin{array}{l}\text { Identifying } \\
\text { theories from a } \\
\text { text in groups }\end{array}$ & $\begin{array}{l}\text { Students } \\
\text { distraction in } \\
\text { group work }\end{array}$ & $\begin{array}{l}\text { Equity of } \\
\text { participation, } \\
\text { increasing } \\
\text { motivation }\end{array}$ & $\begin{array}{l}\text { Initiate } \\
\text { discussion for } \\
\text { a subject, } \\
\text { instructions } \\
\text { provided to } \\
\text { students }\end{array}$ & $\begin{array}{l}\text { Collaborative } \\
\text { discussion. } \\
\text { Contributing } \\
\text { own ideas in a } \\
\text { discussion. }\end{array}$ \\
\hline $\begin{array}{l}\text { Intervention / } \\
\text { Evaluation }\end{array}$ & $\begin{array}{l}\text { CL text } \\
\text { comprehension } \\
\text { activity with } \\
\text { quotes about } \\
\text { theory }\end{array}$ & $\begin{array}{l}\text { CL problem- } \\
\text { solving } \\
\text { activity }\end{array}$ & $\begin{array}{l}\text { CL problem- } \\
\text { solving } \\
\text { activity }\end{array}$ & $\begin{array}{l}\text { CL activity for } \\
\text { discussion and } \\
\text { negotiation }\end{array}$ & $\begin{array}{l}\text { CL activity for } \\
\text { discussion of } \\
\text { course } \\
\text { concepts. }\end{array}$ \\
\hline Collected student data & $\begin{array}{l}\text { Engagement, } \\
\text { content, } \\
\text { student } \\
\text { feedback }\end{array}$ & $\begin{array}{l}\text { Student } \\
\text { feedback, } \\
\text { peer- } \\
\text { assessment }\end{array}$ & $\begin{array}{l}\text { Student } \\
\text { feedback }\end{array}$ & $\begin{array}{l}\text { Engagement, } \\
\text { content, } \\
\text { student } \\
\text { feedback }\end{array}$ & $\begin{array}{l}\text { Engagement, } \\
\text { content }\end{array}$ \\
\hline $\begin{array}{l}\text { Reflections for learning } \\
\text { (re) design }\end{array}$ & $\begin{array}{l}\text { Time } \\
\text { management, } \\
\text { off-task } \\
\text { discussion, } \\
\text { revising } \\
\text { feedback } \\
\text { questions, } \\
\text { dynamic- } \\
\text { enriching } \\
\text { activity, } \\
\text { improved } \\
\text { student } \\
\text { capacity }\end{array}$ & $\begin{array}{l}\text { Time } \\
\text { management, } \\
\text { distraction in } \\
\text { groups, } \\
\text { preparing } \\
\text { students for } \\
\text { complex task } \\
\text { with smaller } \\
\text { activities }\end{array}$ & $\begin{array}{l}\text { Time } \\
\text { management, } \\
\text { increased } \\
\text { participation, } \\
\text { better role } \\
\text { distribution }\end{array}$ & $\begin{array}{l}\text { Technical } \\
\text { problems, } \\
\text { instructions } \\
\text { before the } \\
\text { activity, } \\
\text { elicitations of } \\
\text { ideas }\end{array}$ & $\begin{array}{l}\text { Increased } \\
\text { participation, } \\
\text { time } \\
\text { management, } \\
\text { improved } \\
\text { argumentation }\end{array}$ \\
\hline
\end{tabular}

${ }^{*}$ TS2 $=$ Teacher in School 2

In School 1, the analysis shows that during the design and reflection phase with student data, teachers referred to the subject content and the main learning objectives. However, in School 2, the initial inquiry problem and subsequent reflection referred to students' individual and collaborative skills and reflections 
about perceived usefulness of the task by students. In both schools, all teachers referred to the time management of their intervention. Teachers' reflection were based on the collected data which were visualizations of students' participation in the PyramidApp tool, the content of students' responses and discussions in the Pyramid App tool and student feedback with google forms (see Figure A.1).

Regarding their engagement in the collective process and the online participation behavior of teachers in the two schools, we analyzed their different actions performed within ILDE between November 2016-May 2018. Figures 8-9 show the different online behavior patterns of teachers in School 1 and 2. In School 1, there were more teachers, compared to School 2, who started using ILDE (Figure 8). However, about half of them continued using it by creating, editing, commenting and viewing designs and other members' profiles throughout the time. In School 2, we observe longitudinal engagement throughout the school year with time intervals of high and low participation patterns (Figure 9). In both schools, the professional development program activities influenced their online participation behavior and in School 2 we observed active follow-up participation independently from the PD program.

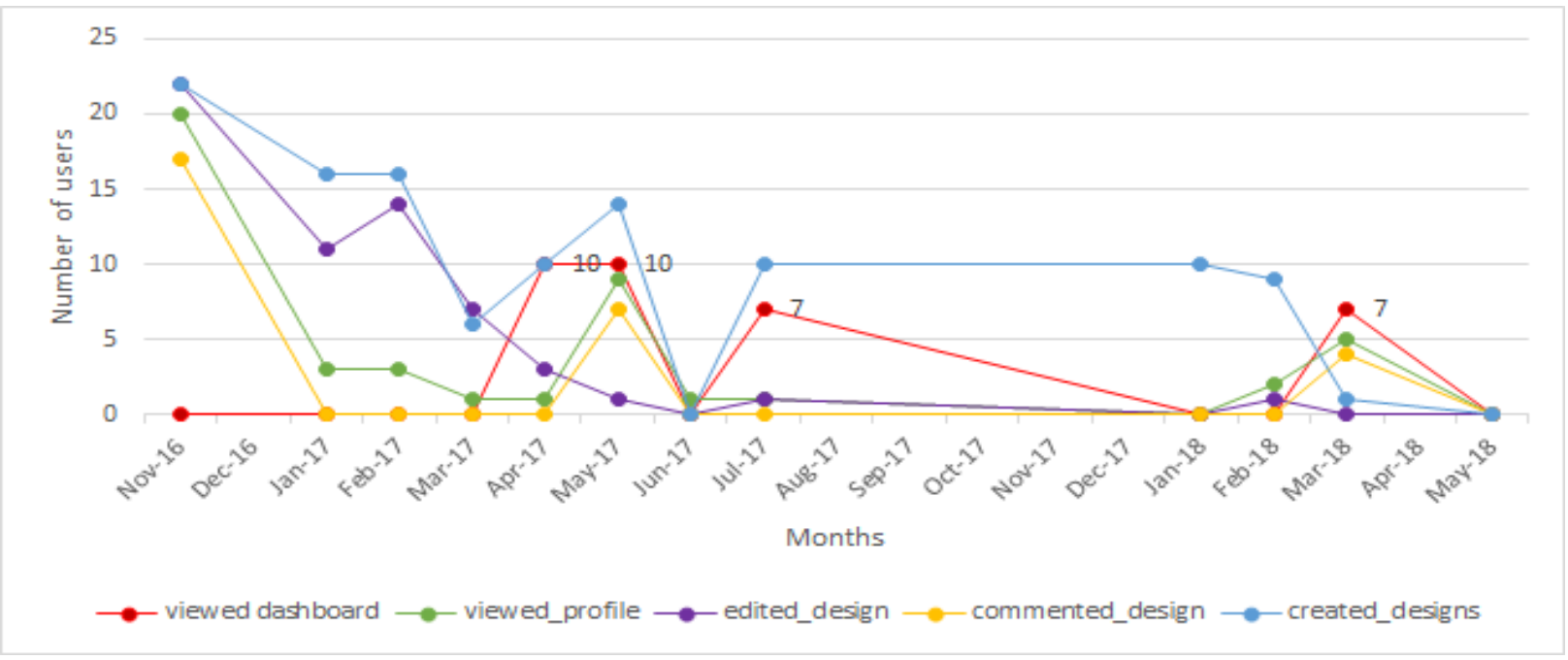

Figure 8. School 1. Members online participation represented with different actions in ILDE across months (viewed_dashboard, viewed_profile, edited_design, commented_design, created design).

The community dashboard aimed at providing awareness in the online teacher community and support the collective process for creating learning designs. Regarding the use of the dashboard, the red line in Figure 8-9 shows that the peak number of users who interacted with the dashboard, aligns with the peak number of users who performed other actions, e.g. created designs or profile views. The community dashboard was integrated into the community platform in May 2017 and influenced the collective behavior of teachers' online participation. 


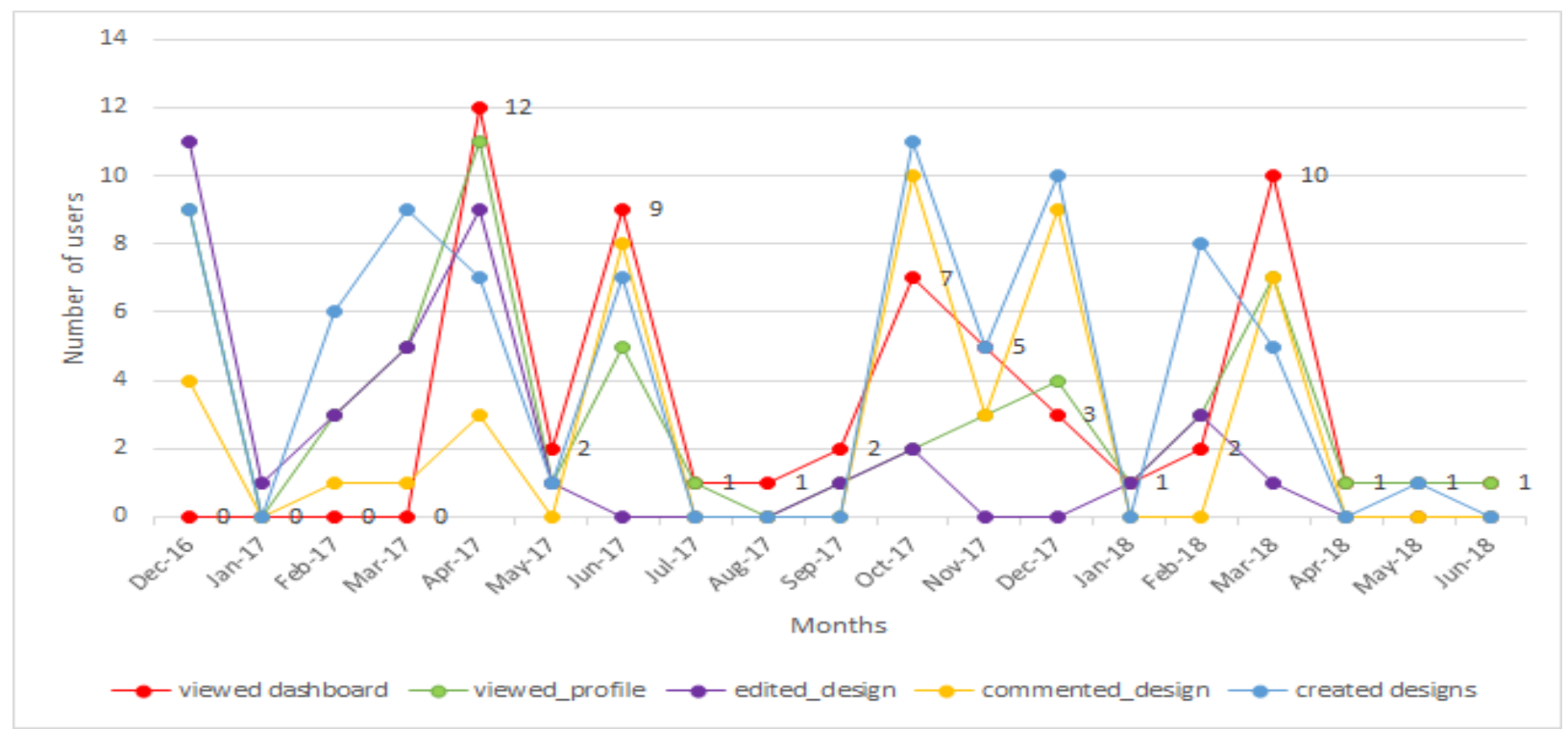

Figure 9. School 2. Members online participation represented with different actions in ILDE across months (viewed_dashboard, viewed_profile, edited_design, commented_design, created design).

\subsubsection{MOOC community}

In the MOOC community, teachers were involved in the collective process of the CIDA framework with the shared learning design artifacts in ILDE and the community awareness dashboard. They were asked to review and comment a pattern-based design for collaborative learning created by other participants. The task was to write two comments; one comment after searching another design without the community awareness dashboard and one comment after using the community dashboard. We performed a content analysis of the comments with the whole comment as a unit of analysis based on the TPACK framework aiming to identify types of knowledge activated by teachers. Table 6 shows examples of teachers' comments and TPACK codes.

Table 6. Analysis of group reflections based on TPACK in a peer-review task with/without the community dashboard in the MOOC.

\begin{tabular}{|c|c|c|}
\hline Code & Meaning & Excerpt \\
\hline TK & $\begin{array}{l}\text { Use of computers without referencing to learning } \\
\text { or teaching }\end{array}$ & $\begin{array}{l}\text { "I have heard of Moodle but never had a chance to } \\
\text { use it. After reading his post I did some research in } \\
\text { order to understand how Moodle works. Afterward, } \\
\text { I have realized that Moodle is much more complex } \\
\text { than the Kahoot or the Popplet. It offers much more } \\
\text { options than the other two programs, but I still do not } \\
\text { mind using both Kahoot and Popplet programs." }\end{array}$ \\
\hline PK & $\begin{array}{l}\text { General teaching and learning strategies or } \\
\text { learning activities. }\end{array}$ & $\begin{array}{l}\text { "I completely agree with you on how Jigsaw can } \\
\text { empower our students if planned right. I usually use } \\
\text { Jigsaw in my reading lessons and for problem- } \\
\text { solution essay braining storming. Using Jigsaw can } \\
\text { trigger students' responsibility, autonomy, and } \\
\text { eventually cooperation." }\end{array}$ \\
\hline
\end{tabular}




\begin{tabular}{|c|c|c|}
\hline CK & Subject-matter regarding a specific topic. & $\begin{array}{l}\text { "This would be a great topic for my advance } \\
\text { business ESL class. They are mainly professionals } \\
\text { who have to deal with these issues daily and they } \\
\text { would all have a different perspective on making this } \\
\text { very interesting." }\end{array}$ \\
\hline TPk & $\begin{array}{l}\text { Use of computers related to teaching/learning } \\
\text { and classroom practice. }\end{array}$ & $\begin{array}{l}\text { "It's a very interesting idea to reflect on forum } \\
\text { publications with PyramidApp activities. But I'd like } \\
\text { to ask you if there are rubrics or rules for forum } \\
\text { posts? Do you discuss them in advance with } \\
\text { students?" }\end{array}$ \\
\hline TCk & $\begin{array}{l}\text { Use of computers to represent subject matter } \\
\text { knowledge. }\end{array}$ & $\begin{array}{l}\text { "I chose this case from the visualizations, because its } \\
\text { title deals with learning and technology, like mine } \\
\text { "How gamification mechanisms can promote } \\
\text { collaboration in Communities of Inquiry" and based } \\
\text { on the existing comment, which I saw that someone } \\
\text { had written about it. As for the relevance that exists } \\
\text { between these two activities, I have to mention their } \\
\text { collaborative nature and the fact that both of them } \\
\text { can be organized and realized using a forum." }\end{array}$ \\
\hline PCk & $\begin{array}{l}\text { Teaching and learning strategies related to } \\
\text { subject matter. }\end{array}$ & $\begin{array}{l}\text { "I have never thought about using the Jigsaw tool for } \\
\text { reading comprehension activities, and I really like } \\
\text { what you have shared. The activity sounds really } \\
\text { engaging and complete. My final degree project } \\
\text { deals with English learning and reading motivation, } \\
\text { and now I will take into account this tool and I'll try } \\
\text { to put your activity into practice asap." }\end{array}$ \\
\hline TPCk & $\begin{array}{l}\text { Integrated use of computers related to teaching } \\
\text { and learning strategies and content knowledge }\end{array}$ & $\begin{array}{l}\text { "Hi, I like your idea of using Jigsaw for the issue. } \\
\text { The issue itself is highly important, I also work with } \\
\text { a similar set of issues at the university level, though } \\
\text { in my case we discuss more about digital identity, } \\
\text { branding, and professional social media interaction. } \\
\text { Any tool to help share ideas and opinion of the peers } \\
\text { on this subject is helpful for students." }\end{array}$ \\
\hline Other & Social appraisal comments and other feedback. & "Very nice practice and very detailed description." \\
\hline
\end{tabular}

$N=34$ teachers out of 100 participated in the task and wrote in total $N=60$ comments. The rest of the teachers did not perform this task, or they provided very limited information. The largest amount of comments included activation of integrated pedagogical and content knowledge ( $\mathbf{P C k}=30 \%)$, then followed isolated pedagogical knowledge $(\mathbf{P K}=25 \%)$, and social appraisal comments (Other $=25 \%)$. The integration of technological pedagogical knowledge was present in $\mathbf{T P C k}=8 \%$ of the comments and followed isolated content knowledge $(\mathbf{C K}=5 \%)$, integrated technological and pedagogical knowledge $(\mathbf{T P k}=3 \%)$ and isolated technological knowledge (TK=1\%). Regarding the differences with/without the use of the community dashboard, more comments appeared with activation of either isolated content knowledge (CK) or integrated pedagogical and content knowledge (PCk) (Figure 10). One interpretation could be that teachers were able to see more titles of designs in the dashboard and they commented the ones with related content to their subject. 


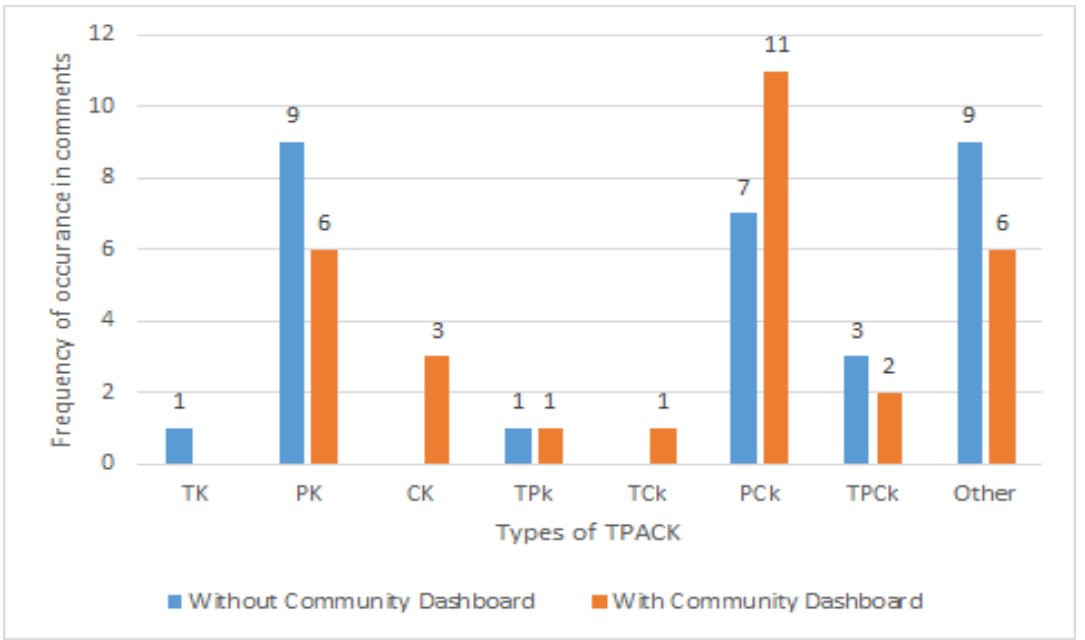

Figure 10. Types of TPACK knowledge activated during the peer-review task with/without using the community dashboard.

Regarding their engagement in the collective process and the online teacher participation, we observed a similar online participation behavior as in School 1. There was a peak number of users who interacted in ILDE during the last day of each week and this aligned with the deadline of the MOOC assignments. Regarding the use of the dashboard, the MOOC participants could access it after the first week of the MOOC. During the weeks 2 and 3, more participants used the dashboard because it was introduced within one assignment, and in weeks 4 and 5, dashboard use decreased (see Figure 11). However, we observed a peak number of participants who interacted with others by commenting and viewing others' profiles and designs and this aligned with the peak number of participants who used the dashboard.

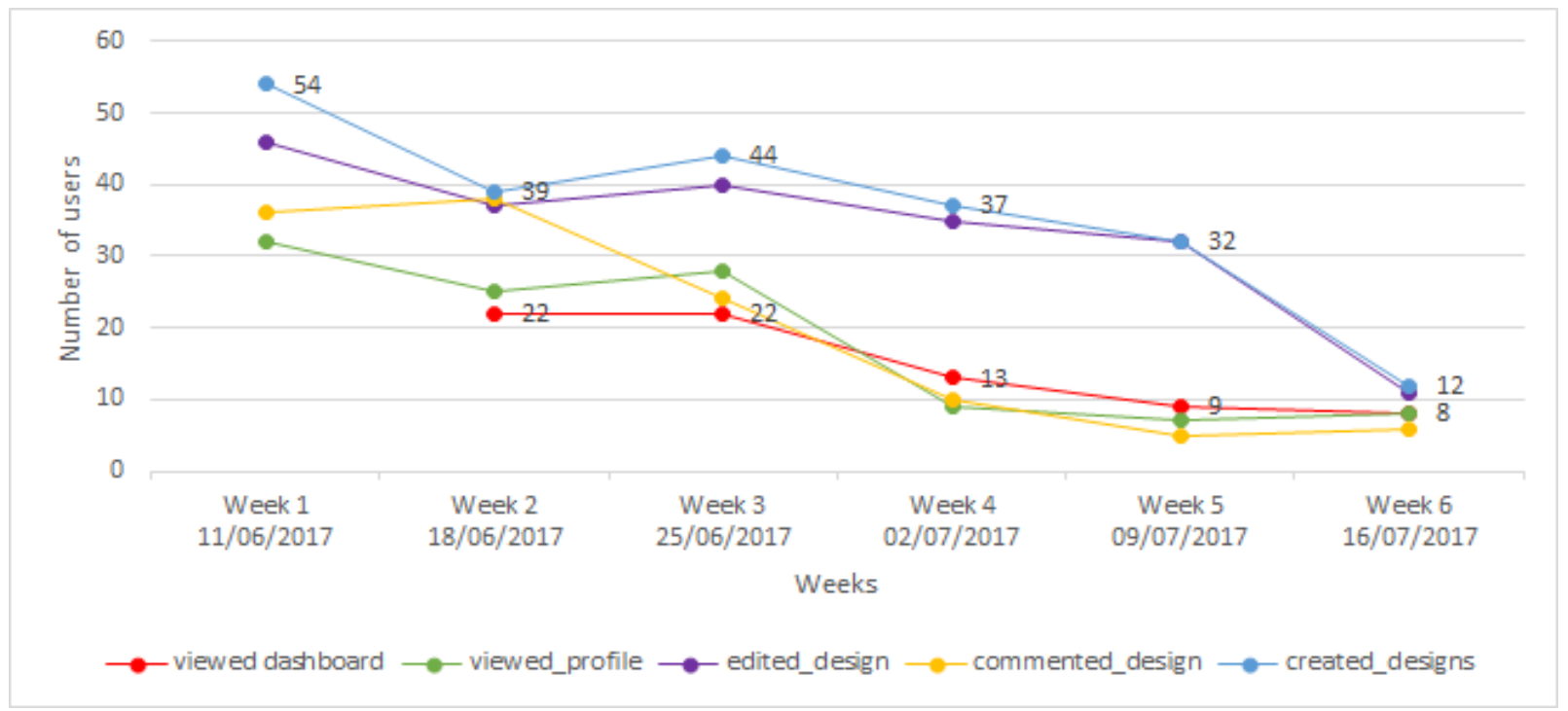

Figure 11. MOOC community. Members online participation represented with different actions in ILDE across months (viewed_dashboard, viewed_profile, edited_design, commented_design, created design).

To analyze the inquiry process in the MOOC, we considered the created learning design artifacts. In this case, teachers did not implement their designs and they didn't use the TILE tool. To understand teachers' 
inquiry process we analyzed their conceptualizations and learning designs. In particular, teachers used conceptualization templates to define their problem and authoring tools (PyramidApp, WebCollage) to describe all the details of their learning design. WebCollage enables the authoring and deployment of CSCL activities based on different patterns in a Virtual Learning Environment (VLE) (Villasclaras-Fernández, Hernández-Leo, Asensio-Pérez, \& Dimitriadis, 2015). N=11 teachers deployed their learning designs in a VLE (Moodle). Table 1 shows the different activities during each week of the MOOC. We initially analyzed the amount of learning design artifacts created with the different tools in ILDE (conceptualization, authoring, and implementation tools) and we focused on the ten most active participants (higher number of produced artifacts). Figure 12 shows ten participants' timeline of created learning design artifacts with different tools. During June 2017, participants worked more on the conceptualization of their design (blue points) and then specified their design solution with different tools. Some participants used the PyramiApp tool (Red points) to design a collaborative learning activity while others used WebCollage (Green points) and deployed it in the VLE (Orange points) Moodle. In the MOOC, participants did not experience an implementation with students, thus they were not able to reflect with student data. The inquiry process followed in the MOOC varied among participants in the levels of engagement, types of tools used and time of engagement.

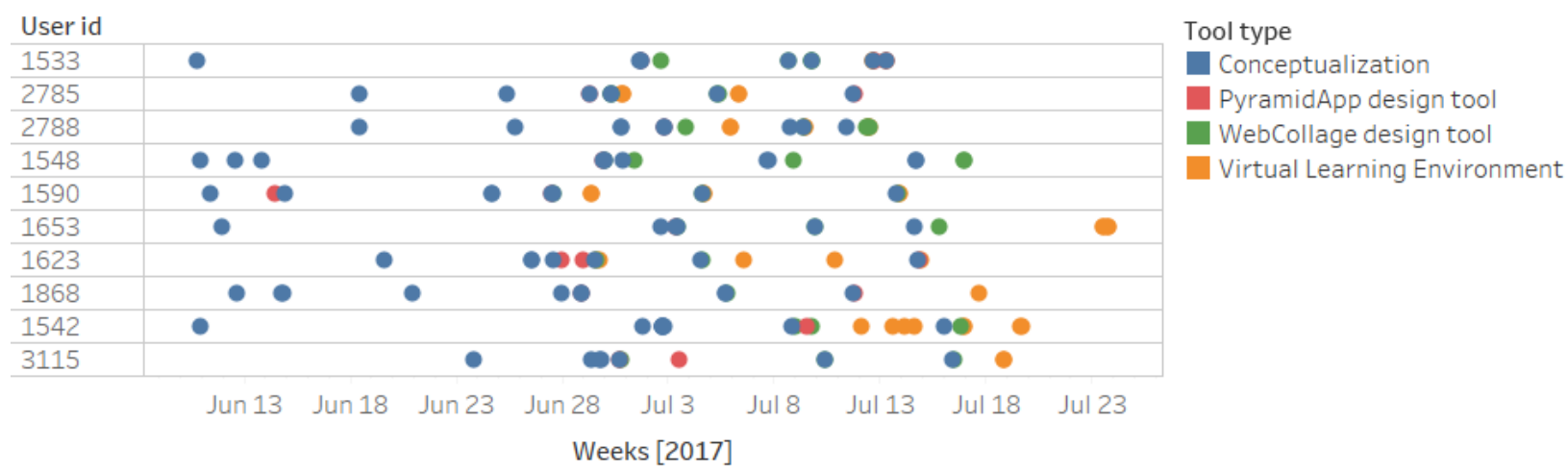

Figure 12. Timeline of participants created learning design artifacts with different ILDE tools. Blue points indicate conceptualization tools such as design templates. Red points indicate the use of the PyramidApp design tool while green points indicate the use of WebCollage design tool. Orange points indicate the deployment of the design in a VLE (Moodle).

To further understand the content of teacher inquiries we conducted an analysis of the learning design artifacts of those ten active participants. Table A. 8 shows the content of the conceptualizations, problems defined by teachers and the proposed designs and solutions. The most common problem appeared in their inquiries was to increase student participation with more reflections and interactions among them. Other participants' conceptualizations referred to student motivation, teamwork experience, and communication skills. The proposed solutions were either CL activities based on the Pyramid pattern with the help of the PyramidApp tool or based on the Jigsaw Pattern with the help of WebCollage tool and Moodle.

\subsection{Teacher perceived usefulness of CIDA (collective, inquiry process and technological support)}




\subsubsection{School communities}

We present analysis related to teacher perceived usefulness of the three framework components. To evaluate the collective process and how teachers perceived data-informed collective inquiry we initially used an instrument for measuring perceived usefulness of the community awareness dashboard (see Table A.1 in the Appendix). The instrument was constructed based on the CHAT framework presented in CIDA and included 12 items regarding the designs, members and tools of the community. Cronbach's alpha for the 12 items was .74. In total $N=23$ teachers responded to the questionnaire and results propose that they appreciated all the community information presented in the dashboard (Designs tab: $M=3.73, S D=.62$, Members tab: $M=3.90, S D=.65$, Tools tab: $M=4.23, S D=.60$ )

Additionally, regarding the collective process we conducted seven semi-structured interviews in the two schools covering $50 \%$ of the participants who performed classroom implementations. Table A.2 in the Appendix shows the interview questions. The question "Please explain your experience about the group reflections in the project" aimed to evaluate teachers' collective inquiry with student data (Table 7). We transcripted the interviews and analyzed segments with different or common topics. This resulted in 16 segments. Most of the segments (5) referred to the value of sharing problems, solutions and impressions for classroom implementations. Then followed topics such as the value of new information and ideas by other teachers, the importance to have common spaces to discuss pedagogical issues and the value for jointly reflecting on such topics. Lastly, two segments referred to the importance of dedicating more time and to follow up reflection meeting which emerged after the professional activities.

Table 7. Sample of teachers' answers in the question "Please explain your experience about the group reflections in the project".

\begin{tabular}{|c|c|c|c|}
\hline Topic & Explanation & Excerpt & Frequency \\
\hline $\begin{array}{l}\text { Shared } \\
\text { problems/solutions/ } \\
\text { impressions }\end{array}$ & $\begin{array}{l}\text { Valuing the shared } \\
\text { problems, solutions and } \\
\text { impressions for teachers' } \\
\text { practices. }\end{array}$ & $\begin{array}{l}\text { "Participating in the reflections is } \\
\text { useful to find joint solutions and have } \\
\text { empathy with the same problems that } \\
\text { others have." }\end{array}$ & 5 \\
\hline Informative/New ideas & $\begin{array}{l}\text { Valuing new information } \\
\text { and ideas by others }\end{array}$ & $\begin{array}{l}\text { "It can give you ideas of things that } \\
\text { you have not applied." }\end{array}$ & 3 \\
\hline Spaces for pedagogy & $\begin{array}{l}\text { Valuing the common } \\
\text { space to discuss aspects } \\
\text { about pedagogy }\end{array}$ & $\begin{array}{l}\text { "We have found a space to explain } \\
\text { what our techniques are, our strategies } \\
\ldots \text { and how they are applied. I find it } \\
\text { interesting, it's more, it seems to me } \\
\text { that this is necessary. In fact, I think it } \\
\text { should be mandatory because we learn } \\
\text { a lot. You really see some practices } \\
\text { that work, and then also the reflections } \\
\text { of the teachers in what they evaluate ... } \\
\text { etc. it helps you to make a more plural } \\
\text { panorama of all learning" }\end{array}$ & 3 \\
\hline Valuable joint reflection & $\begin{array}{l}\text { Valuing the joint } \\
\text { reflections }\end{array}$ & $\begin{array}{l}\text { "Whenever a reflection process is } \\
\text { performed jointly, I think it is very } \\
\text { important" }\end{array}$ & 3 \\
\hline Follow up reflections & $\begin{array}{l}\text { Dedicating more time for } \\
\text { follow up reflections }\end{array}$ & $\begin{array}{l}\text { "I decided to do it with X (of tutorial } \\
\text { action) and generated spaces for } \\
\text { reflection, not within the sessions- } \\
\text { workshop, but ... so we reviewed }\end{array}$ & 2 \\
\hline
\end{tabular}




\begin{tabular}{|l|l|l|l|}
\hline & $\begin{array}{l}\text { activities that we did in tutoring ... and } \\
\text { how to think about them to improve } \\
\text { them, we suddenly decided to make a } \\
\text { resource bank for tutorial action” }\end{array}$ & \\
\hline
\end{tabular}

Regarding the inquiry process, we conducted interviews with seven teachers (50\%) and seven more teachers were asked to fulfill a questionnaire with the same questions (see Table A.3). We used a thematic analysis of the main topics extracted from the interviews and the open questions regarding the perceived usefulness of the teacher inquiry process with the TILE tool and the use of student data to inform learning design. Table A.5 and A.6 show the main topics and sample of teachers' answers.

Teachers valued the systematic way to collect student information during classroom activities and the connection of their design expectations with their objective evaluation based on student data. Moreover, teachers explained that the teacher inquiry process is a practical way to reflect on the design and reflection on classroom implementations. They mentioned that the teacher inquiry process with the TILE tool provided awareness and orientation for key elements to reflect on design. According to the teachers, it was also a way to document the whole inquiry process for later review. Lastly, teachers mentioned in their interviews barriers for systematic teacher inquiry with student data. The barriers referred to the lack of available time, large student cohorts and difficulties with ICT tools.

Teachers also valued the use of data for improving future implementations of their learning designs. They appreciated the real-time collection of student information during learning activities' implementations. Student feedback with questionnaires was also one aspect which was valuable for improving their learning designs. Teachers also explained the key elements for which student data can help. These elements were the identification of student misunderstandings, improvement of instructions and management of time during classroom activities.

\subsubsection{MOOC community}

To evaluate the collective process, after the accomplishment of the MOOC, $N=29$ participants responded to two open-ended questions regarding the use of the community awareness dashboard. The first question asked participants if the dashboard facilitated an understanding of the community participation and how it helped them to accomplish their tasks. Participants' responses referred to the three different dashboard tabs about the created designs, the learning design tools and the community members. For instance, they mentioned that the dashboard helped to find, re-use, comment designs created by others and identify ideas for their classrooms. With respect to the tools and the community members, they pointed out that the dashboard allowed a better understanding of the community members' participation and the use of the learning design tools.

In the second question, participants were asked to provide their feedback about the dashboard and recommendations for future improvements. The main topics based on their comments were that the dashboard allows an understanding of the community dynamics, members' social interactions and the identification of resources based on community data. Participants suggested to add social ratings about the quality of the different learning design artifacts and use the dashboard in more tasks during the course. 
To evaluate the inquiry process in the MOOC, we used three Likert scale questions (1-7) after the completion of the MOOC about the perceived usefulness of the ILDE tools (conceptualization, authoring, and implementation tools). $N=34$ participants responded to the questionnaire. Table 9 shows the percent of teachers' responses about perceived usefulness of the tools. All tools (conceptualization, authoring, implementation) received high values by teachers. The highest values were given to conceptualization and authoring tools and the lowest to implementation tools. This was contradictory in the responses of 9 participants who deployed their designs in a VLE. In this case, they rated higher the implementation tools, followed by the authoring and conceptualization tools. The fact that few participants deployed their designs in a VLE can explain lower perceived usefulness of the implementation tools. In general, considering the use of the ILDE tools as the inquiry process in the MOOC, perceived usefulness varied according to participants' engagement with the different tools.

Table 9. Percent of teachers' responses about the usefulness of ILDE tools $(N=34)$

\begin{tabular}{|c|c|c|c|c|c|c|c|}
\hline \multicolumn{8}{|c|}{$\begin{array}{l}\text { Question: The conceptualization, authoring, implementation } \\
\text { features of ILDE are useful. }\end{array}$} \\
\hline \multirow[b]{2}{*}{ Conceptualization tools } & \multicolumn{5}{|c|}{ Disagree } & \multicolumn{2}{|c|}{ Agree } \\
\hline & 0 & 0 & 15 & 6 & 9 & 56 & 15 \\
\hline Authoring tools & 0 & 0 & 9 & 6 & 15 & 47 & 21 \\
\hline Implementation tools & 0 & 6 & 6 & 12 & 15 & 41 & 21 \\
\hline
\end{tabular}

\section{Results}

The analysis of the proposed CIDA framework in the three case studies; two school communities and MOOC community, inform the articulation of the framework. Based on the three components; collective process, inquiry process, technological support and their relationships we evaluated our research questions. Table 10 shows the main findings of the cross-case analysis in the three case studies.

Table 10. Cross-case analysis in three cases based on the framework and research questions.

\begin{tabular}{|c|c|c|c|c|}
\hline \multirow{3}{*}{\multicolumn{2}{|c|}{ CIDA framework }} & \multirow[t]{3}{*}{ Cases } & \multicolumn{2}{|c|}{$\begin{array}{l}\text { RQ1: Does the framework help to study and support } \\
\text { participatory teacher design practice enhanced with data } \\
\text { analytics? }\end{array}$} \\
\hline & & & \multicolumn{2}{|c|}{$\begin{array}{l}\text { RQ2: How does the framework help to study and support } \\
\text { participatory teacher design practice enhanced with data } \\
\text { analytics? }\end{array}$} \\
\hline & & & $\begin{array}{l}\text { RQ2a: How do teachers } \\
\text { engage with data-informed } \\
\text { collective inquiry processes? }\end{array}$ & $\begin{array}{l}\text { RQ2b: How do teachers } \\
\text { perceive data-informed } \\
\text { collective inquiry processes? }\end{array}$ \\
\hline & $\begin{array}{l}\text { Technological } \\
\text { Support }\end{array}$ & & & \\
\hline Collective & ILDE, inILDE, & School & -Different online collective & -Value in sharing problems \\
\hline
\end{tabular}




\begin{tabular}{|c|c|c|c|c|}
\hline \multirow[t]{2}{*}{ Process } & TILE & $\begin{array}{l}\text { communities } \\
\text { (two } \\
\text { schools) }\end{array}$ & $\begin{array}{l}\text { teacher participation between } \\
\text { schools. } \\
\text {-Collective participation was } \\
\text { influenced by community } \\
\text { dashboard. } \\
\text {-Frequent pedagogical } \\
\text { knowledge activation and } \\
\text { social appraisals in teachers' } \\
\text { interactions. }\end{array}$ & $\begin{array}{l}\text { and solutions for classroom } \\
\text { inquiry, ideas by teachers, } \\
\text { common spaces for } \\
\text { pedagogical reflections. }\end{array}$ \\
\hline & $\begin{array}{l}\text { ILDE, } \\
\text { inILDE }\end{array}$ & $\begin{array}{l}\text { MOOC } \\
\text { community }\end{array}$ & $\begin{array}{l}\text {-Collective participation } \\
\text { decreased over time. } \\
\text {-Collective participation was } \\
\text { influenced by community } \\
\text { dashboard. } \\
\text {-Frequent integrated } \\
\text { pedagogical content } \\
\text { knowledge activation and } \\
\text { social appraisals in teachers' } \\
\text { interactions. }\end{array}$ & $\begin{array}{l}\text {-Understanding the } \\
\text { community, find and re-use } \\
\text { design ideas, inspiration for } \\
\text { design. }\end{array}$ \\
\hline \multirow[t]{2}{*}{$\begin{array}{l}\text { Inquiry } \\
\text { Process }\end{array}$} & $\begin{array}{l}\text { ILDE, inILDE, } \\
\text { TILE }\end{array}$ & $\begin{array}{l}\text { School } \\
\text { communities } \\
\text { (two } \\
\text { schools) }\end{array}$ & $\begin{array}{l}\text {-Different levels of } \\
\text { engagement and elaboration in } \\
\text { inquiry cycles. } \\
\text {-Inquiry problem formulation } \\
\text { was based on subject content, } \\
\text { student skills, and objectives. } \\
\text {-Data-informed reflections } \\
\text { focused on student feedback } \\
\text { about the task and initial } \\
\text { inquiry problem. }\end{array}$ & $\begin{array}{l}\text {-A systematic and practical } \\
\text { way to collect student data in } \\
\text { classroom activities. } \\
\text {-Documentations facilitate } \\
\text { future reflections. } \\
\text {-Awareness \& orientation for } \\
\text { teacher inquiry steps. } \\
\text {-Data use informed } \\
\text { instructions, time } \\
\text { management, and student } \\
\text { misunderstandings. } \\
\text {-Factors to consider for } \\
\text { performing teacher inquiry: } \\
\text { lack of time, large student } \\
\text { cohorts and familiarity with } \\
\text { ICT tools. }\end{array}$ \\
\hline & ILDE, inILDE & $\begin{array}{l}\text { MOOC } \\
\text { community }\end{array}$ & $\begin{array}{l}\text {-Differences in levels of } \\
\text { engagement, types of tools } \\
\text { used and time of engagement } \\
\text {-Inquiry problem formulation } \\
\text { focused on student } \\
\text { participation, interactions, and } \\
\text { collaborative skills. }\end{array}$ & $\begin{array}{l}\text {-Perceived usefulness of ILDE } \\
\text { tools (conceptualization, } \\
\text { authoring, implementation) } \\
\text { varied according to } \\
\text { participants' engagement with } \\
\text { each tool. }\end{array}$ \\
\hline
\end{tabular}

With respect to RQ1, we analyzed the three different community cases to understand if the CIDA framework helps to study and support participatory teacher design practice enhanced with data analytics. The results show the applicability of the framework components and their relationships in investigating and supporting teachers in technological environments. Teachers' individual and collective reflections show evidence of knowledge building which contributes to their professional development. The details about how the framework helps to study and support the cases were analyzed through RQ2, where we addressed 
how teachers engaged with and perceived the CIDA components and their data-informed reflections. We discuss the results based on the CIDA components and their connections.

Regarding the relationship between the collective process and technological support, there was a decrease in online teacher participation throughout the time in all cases; school communities and MOOC community. The TPD activities in schools and the learning activities in the MOOC explain teachers' online participation patterns. However, teachers in one of the schools engaged longer with ILDE independently of the TPD activities. They also implemented more learning activities, and this could explain why they were interested to use again ILDE. Teacher participation patterns align with relevant literature about factors in sustaining collective participation in formally-organized online teacher communities. These factors often include the available "free" time for teachers, lack of familiarity in working with asynchronous ways and the moderation by program leaders (Lantz-Andersson, Lundin \& Selwyn, 2018).

In all cases, the use of the community awareness dashboard (data-informed collective process) influenced the collective participation of the teachers. The most active teachers used more frequently the dashboard compared to the less active ones and this shows that one characteristic of active participants' role was the monitoring of their community. Thus, the integration of a community awareness dashboard in an online teacher community provides added value to key community members as they can better search information and regulate their contribution behavior in their community (Michos \& Hernández-Leo, 2018; Klamma, 2013). Both active and inactive participants were able to reflect and understand the collective participation which can resolve problems derived from asynchronous communication.

In the school communities, the content of teachers' collective reflections shows evidence of higher pedagogical knowledge activated in their comments and this was combined with social appraisals. In the MOOC community, teachers activated more integrated pedagogical content knowledge with frequent social appraisals. However, the proposed task by facilitators was different. In the school communities, teachers reflected on learning design implementations with student data and in the MOOC case, teachers reflected on other teachers' conceptual designs with other teachers' data. One interpretation could be that teachers' collective reflection with learning analytics leads to more pedagogically-oriented discussions whereas reflections on conceptual designs lead to integrated pedagogical and content discussion. In all cases, teachers' comments were lacking the integration of technology with pedagogy and content and this is contradictory in studies about teachers' design teams (Boschman, McKenney, Voogt, 2015; Kali, Markauskaite, Goodyear, \& Ward, 2011). A combination of different coding schemes would shed more light about teachers' collective reflections with educational data (e.g. the coding scheme by Boschman, McKenney, Voogt, 2015 about practical, internal and external constraints of teachers). The different types of TPACK activated during teachers' reflections shows evidence of pedagogical knowledge building in the three investigated inquiry communities.

The collective process and its relationship with the technological support were positively received by teachers in the analyzed cases. In schools, the main argument based on their interviews was that it helps to share problems and solutions for classroom inquiry, to learn new ideas by others and have shared spaces for collective reflections. These elements include common characteristics in professional teacher communities (Popp \& Goldman, 2016). Moreover, in the MOOC, teachers explained that the community dashboard facilitated understanding of their community and inspiration from others' design ideas. The 
perceived value of sharing within the community aligns with the content analysis of their comments and shows that sharing enables knowledge building about learning design and teaching practice (Hong et al., 2019).

Regarding the inquiry process and its connection with the technological support, teacher engagement in inquiry cycles and the content of their inquiries show value in cultivating teacher reflective practice (Mandinach, \& Jimerson, 2016; Van Gasse et al., 2017). Additionally, the sharing of reflective documentations enabled collaborative inquiry (including all CIDA components) and co-regulation for teaching problems and solutions (Butler \& Schnellert, 2012). This also relates to the development of selfregulative knowledge by teachers (Littlejohn \& Hood, 2017) through the inquiry process. Log data analysis about the use of the TILE inquiry tool shows different levels of engagement in the school communities. Their engagement with the inquiry process aligns with results about the collective process as teachers' working life and available time are important factors for online teacher participation and can explain this behavior (Lantz-Andersson, Lundin \& Selwyn, 2018). Teachers defined their inquiry problems based on their subject content, learning design objectives and students' skills. Their reflections drew upon the available student data and referred back to the initial inquiry problems and students' perception about the task. In the MOOC case, teachers' inquiry process was analyzed based on learning design tools available in ILDE. In this case, teachers also showed varied levels of high and low engagement and their inquiry problems referred to student participation, students' interaction and students' collaborative skills.

The inquiry process supported by technology included the implementation of collaborative learning activities and the collection and interpretation of student data. Teachers valued the real-time collection of student data during the implementation of learning activities, the orientation to perform inquiries with the TILE tool and the documentation of the whole inquiry process. Teachers mentioned key elements for which learning analytics can be used for learning design like the improvement of instructions, time management and identification of student misunderstandings (Michos, Hernández-Leo, Albó, 2018). In the MOOC community, teachers perceived useful the range of conceptualization, authoring tools but less useful the implementation tools because they did not implement their learning designs which further shows that the whole design life-cycle can be more meaningful and informative for teachers (Asensio-Pérez et al., 2017).

\section{Discussion and Conclusions}

Design approaches for teachers facilitate reflection on the integration of new technologies into their everyday teaching practices. Increasing studies acknowledge the shifting from individual to collective teacher practices for anytime and self-directed professional learning (Prestridge, 2019). To support collective teacher practices, web-technologies are used for the sharing of teacher artifacts, resources, collective contributions, and knowledge exchange.

In this paper, we propose the CIDA framework to study and support the collective and inquiry process of teachers as designers in technological environments. The framework was articulated after performing the following steps: a) two studies in teacher communities related to learning design and learning analytics (Michos \& Hernández-Leo, 2018; Michos, Hernández-Leo, \& Albo, 2018), b) a literature review in frameworks about collective inquiry for knowledge building with technologies. The framework includes three interconnected components to support teachers as designers: the inquiry process, the collective 
process, and technological support. Regarding technological support, ILDE was used for creating and sharing learning designs. A community awareness dashboard (inILDE) was implemented into ILDE to support the collective process with data analytics and an inquiry tool for teachers (TILE) was implemented to support the inquiry process with learning analytics. Towards cultivating teacher reflective practices, we showed how data collected from teachers in the web-based platform and data collected from students in TEL scenarios can inform teacher collective inquiry. We provide evidence from three inquiry communities of teachers; two school communities and a MOOC community who were involved in TPD programs. In these programs, teachers reflected upon the teacher and student data (learning designs and learning analytics).

The results obtained from the three case studies inform further the practical implementation of the CIDA framework:

- TPD programs need to consider teacher training in reflective learning design with learning analytics. In this context, teachers online and face-to-face discussions can build theoretical and practical knowledge drawn from experiences. Guidance by program coordinators (e.g., tutor facilitated discussion) need to be integrated into the TPD programs so that teachers develop integrated knowledge (e.g., integrated TPACK).

- The asynchronous and varied levels of teachers' engagement with collective inquiry can be supported with community platforms and community awareness tools which display aggregated teacher data.

- The implementation of the whole inquiry cycle by teachers adds more value to the collective knowledge which can be shared, re-used and discussed.

- Teacher roles can be distinguished between co-designers who provide peer-feedback and contribute to the collective process and enactors who complete the whole inquiry cycle.

- Technological support needs to consider the types of artifacts produced by different inquiry tools so that teachers can share, reuse, discuss and analyze the inquiry process. This can further support the collective process.

The contribution of this paper can inform research in the context of teachers as designers of learning environments (Laurillard, 2013; Goodyear, 2015; Kali, McKenney, \& Sagy, 2015; Persico, Pozzi, \& Goodyear, 2018) and future implementation in related TPD programs with technologies. Moreover, this paper informs the strand of research about teacher professional learning in web-based communities (Tseng \& Kuo, 2014; Hong et al., 2019; Prestridge, 2019) by providing empirical evidence of teacher engagement and perceptions. The CIDA framework and its elements can inspire and guide future research in teacher communities who use other technologies such as social networks (e.g., Twitter, Facebook) or VLEs (e.g. Moodle). Last, this paper proposes technologies and data analytics supports for inquiry communities of teachers and it is connected with research in (collaborative) teacher inquiry (Butler, \& Schnellert, 2012; Mor, Ferguson, \& Wasson, 2015). Future work should consider the development of ready-to-use surveys based on the framework considering all its three components.

Additionally, the framework can provide design guidance to practitioners. Teachers and teacher educators can use elements of the CIDA framework to develop skills related to digital pedagogy and reflect upon TPD programs with technologies. System developers can also use the framework as an integrated view of teacher design practices with technologies. This will allow the development of tools for teachers and teacher 
communities similar to the ones proposed in this paper. As a conclusion, the contribution of this paper aims to inform researchers, teachers and system developers by considering the three interconnected components: the inquiry process, the collective process, technological support and their relationships.

\section{References}

Alhadad, S. S., \& Thompson, K. (2017). Understanding the mediating role of teacher inquiry when connecting learning analytics with design for learning. Interaction Design and Architecture(s) Journal - IxD\&A, N.33, 54-74.

Agostinho, S., Lockyer, L., \& Bennett, S. (2018). Identifying the characteristics of support Australian university teachers use in their design work: Implications for the learning design field. Australasian Journal of Educational Technology, 34(2), 1-15.

Amiel, T., \& Reeves, T. C. (2008). Design-based research and educational technology: Rethinking technology and the research agenda. Journal of Educational Technology \& Society, 11(4), 29.

Asensio-Pérez, J. I., Dimitriadis, Y., Pozzi, F., Hernández-Leo, D., Prieto, L. P., Persico, D., \& Villagrá-Sobrino, S. L. (2017). Towards teaching as design: exploring the interplay between full-lifecycle learning design tooling and teacher professional development. Computers \& Education, 114, 92-116.

Bannan-Ritland, B. (2014). Teacher design research: An emerging paradigm for teachers' professional development. In Handbook of design research methods in education (pp. 264-280). Routledge.

Berry, B., Johnson, D., \& Montgomery, D. (2005). The power of teacher leadership. Educational Leadership, 62(5), 56-60.

Beetham, H., \& Sharpe, R. (Eds.) (2013). Rethinking pedagogy for a digital age: Designing for 21 st century learning. London:Routledge

Binkhorst, F., Handelzalts, A., Poortman, C. L., \& van Joolingen, W. R. (2015). Understanding teacher design teams - A mixed methods approach to developing a descriptive framework. Teacher and Teacher Education, 51, 213-224

Bolam, R., McMahon, A., Stoll, L., Thomas, S., Wallace, M., Greenwood, A., Hawkey, K., Ingram, M., Atkinson, A. \& Smith, M. (2005). Creating and sustaining effective professional learning communities. Research Report 637. London: DfES and University of Bristol

Boschman, F., McKenney, S., \& Voogt, J. (2015). Exploring teachers' use of TPACK in design talk: The collaborative design of technology-rich early literacy activities. Computers \& education, 82, 250-262.

Butler, D. L., \& Schnellert, L. (2012). Collaborative inquiry in teacher professional development. Teaching and teacher education, 28(8), 1206-1220.

Butler, D. L., Schnellert, L., \& MacNeil, K. (2015). Collaborative inquiry and distributed agency in educational change: A case study of a multi-level community of inquiry. Journal of Educational Change, 16(1), 1-26.

Clarke, A., \& Erickson, G. L. (Eds.). (2003). Teacher inquiry: Living the research in everyday practice. Psychology Press. 
Cober, R., Tan, E., Slotta, J., So, H. J., \& Könings, K. D. (2015). Teachers as participatory designers: Two case studies with technology-enhanced learning environments. Instructional Science, 43(2), 203-228.

Cochran-Smith, M., \& Lytle, S. L. (2009). Inquiry as stance: Practitioner research in the next generation. New York: Teachers College Press.

Conole, G., (2010). Learning design - Making practice explicit. In ConnectEd 2010: 2nd International conference on Design Education, Sidney, Australia, retrieved from http://oro.open.ac.uk/21864/ Last accessed: December 2018

Conole, G. (2013). Designing for learning in an open world. New York, Springer.

Creswell, J. W., \& Plano Clark, V. L. (2007). Designing and conducting mixed methods research. Thousand Oaks, CA: Sage

Dalziel, J., Conole, G., Wills, S., Walker, S., Bennett, S., Dobozy, E., Cameron, L., Badilescu-Buga, E. and Bower, M. (2016). The larnaca declaration on learning design. Journal of Interactive Media in Education, 2016 (1), 1-24, 7 https://doi.org/10.5334/jime.407

Dana, N., \& Yendol-Hoppey, D. (2014). The Reflective Educator's Guide to Classroom Research: Learning to Teach and Teaching to Learn Through Practitioner Inquiry. London: Corwin.

Engestrom, Y. (2000). Activity theory as a framework for analyzing and redesigning work. Ergonomics, 43(7), 960974.

Ferguson, R. (2012). Learning analytics: drivers, developments and challenges. International Journal of Technology Enhanced Learning, 4(5-6), 304-317.

Garrison, D. R., Anderson, T., \& Archer, W. (2001). Critical thinking, cognitive presence, and computer conferencing in distance education. American Journal of distance education, 15(1), 7-23.

Garrison, D. R., \& Arbaugh, J. B. (2007). Researching the community of inquiry framework: Review, issues, and future directions. The Internet and Higher Education, 10(3), 157-172.

Goodyear, P. (2015). Teaching as design. Herdsa review of higher education, 2, 27-50.

Hernández-Leo, D., Asensio-Pérez, J. I., Derntl, M., Pozzi, F., Chacon-Perez, J., Prieto, L. P., \& Persico, D. (2018a). An Integrated Environment for Learning Design. Frontiers in ICT, 5, 9. doi: 10.3389/fict.2018.00009

Hernández-Leo, D., Martinez-Maldonado, R., Pardo, A., Muñoz-Cristóbal, J. A., \& Rodríguez-Triana, M. J. Analytics for learning design: A layered framework and tools (2018b). British Journal of Educational Technology. https://doi.org/10.1111/bjet.12645

Hofman, R. H., \& Dijkstra, B. J. (2010). Effective teacher professionalization in networks? Teaching and Teacher Education, 26(4), 1031-1040.

Hong, H. Y., Lin, P. Y., Chai, C. S., Hung, G. T., \& Zhang, Y. (2019). Fostering design-oriented collective reflection among preservice teachers through principle-based knowledge building activities. Computers \& Education. 130 (Mar. 2019), 105-120. 
Johnson, D. W., \& Johnson, R. T. (1994). Learning Together and Alone: Cooperative, Competitive, and Individualistic Learning. Boston: Allyn \& Bacon.

Kali, Y., Eylon, B.S., McKenney, S., \& Kidron, A. (2018b). Design-centric research-practice partnerships: Three key lenses for building productive bridges between theory and practice. In J. M. Spector, B. Lockee, \& M. Childress (Eds.), Learning, design, and technology. Cham: Springer. (pp. 1-30).

Kali, Y., Markauskaite, L., Goodyear, P., \& Ward, M-H. (2011). Bridging multiple expertise in collaborative design for technology-enhanced learning. Proceedings of the Computer Supported Collaborative Learning (CSCL) Conference (pp. 831-835). Hong Kong: ISLS

Kali, Y., McKenney, S., \& Sagy, O. (2015). Teachers as designers of technology enhanced learning. Instructional Science, 43(2), 173-179.

Khlaif, Z., Gok, F., \& Kouraïchi, B. (2019). How teachers in middle schools design technology integration activities. Teaching and Teacher Education, 78, 141-150.

Kimmerle, J., Cress, U., \& Held, C. (2010). The interplay between individual and collective knowledge: technologies for organisational learning and knowledge building. Knowledge Management Research \& Practice, 8(1), 33-44.

Klamma, R. (2013). Community learning analytics-challenges and opportunities. In International Conference on Web-Based Learning (pp. 284-293). Springer, Berlin, Heidelberg.

Koehler, M., \& Mishra, P. (2009). What is technological pedagogical content knowledge (TPACK)? Contemporary issues in technology and teacher education, 9(1), 60-70.

Kovanović, V., Gašević, D., Joksimović, S., Hatala, M., \& Adesope, O. (2015). Analytics of communities of inquiry: Effects of learning technology use on cognitive presence in asynchronous online discussions. The Internet and Higher Education, 27, 74-89.

Krumm, A., Means, B., \& Bienkowski, M. (2018). Learning Analytics Goes to School: A Collaborative Approach to Improving Education. New York, NY: Routledge.

Lantz-Andersson, A., Lundin, M., \& Selwyn, N. (2018). Twenty years of online teacher communities: A systematic review of formally-organized and informally-developed professional learning groups. Teaching and Teacher Education, 75, 302-315.

Laurillard, D., Kennedy, E., Charlton, P., Wild, J., \& Dimakopoulos, D. (2018). Using technology to develop teachers as designers of TEL: Evaluating the learning designer. British Journal of Educational Technology, 49(6), 1044-1058.

Laurillard, D. (2012). Teaching as a design science: Building pedagogical patterns for learning and technology. New York, NY: Routledge.

Ley, T., Cook, J., Dennerlein, S., Kravcik, M., Kunzmann, C., Pata, K., Purma, J., Sandars, J., Santos, P., Schmidt, A. and Al-Smadi, M. (2014). Scaling informal learning at the workplace: A model and four designs from a large-scale design-based research effort. British Journal of Educational Technology, 45(6), 1036-1048. 
Littlejohn, A., \& Hood, N. (2017). How educators build knowledge and expand their practice: The case of open education resources. British Journal of Educational Technology, 48(2), 499-510.

Littlejohn, A., Milligan, C., \& Margaryan, A. (2012). Charting collective knowledge: Supporting self-regulated learning in the workplace. Journal of Workplace Learning, 24(3), 226-238.

Luckin, R., Clark, W., Avramides, K., Hunter, J., \& Oliver, M. (2017). Using teacher inquiry to support technologyenhanced formative assessment: a review of the literature to inform a new method. Interactive Learning Environments, 25(1), 85-97.

Macià, M., \& García, I. (2016). Informal online communities and networks as a source of teacher professional development: A review. Teaching and teacher education, 55, 291-307.

Manathunga, K., \& Hernández-Leo, D. (2018). Authoring and enactment of mobile pyramid-based collaborative learning activities. British Journal of Educational Technology, 49(2), 262-275.

Mandinach, E. B., \& Jimerson, J. B. (2016). Teachers learning how to use data: A synthesis of the issues and what is known. Teaching and Teacher Education, 60, 452-457

Matuk, C. F., Linn, M. C., \& Eylon, B. S. (2015). Technology to support teachers using evidence from student work to customize technology-enhanced inquiry units. Instructional Science, 43(2), 229-257.

McCoy, C., \& Shih, P. (2016). Teachers as producers of data analytics: a case study of a teacher-focused educational data science program. Journal of Learning Analytics, 3(3), 193-214.

Michos, K., \& Hernández-Leo, D. (2018). Supporting awareness in communities of learning design practice. Computers in Human Behavior, 85 (Aug. 2018), 255-270.

Michos, K., Hernández-Leo, D, Albó, L. (2018). Teacher-led inquiry in technology-supported school communities. British Journal of Educational Technology. 49(6), 1077-1095.

Moon, J. A. (1999). Reflection in learning and professional development: Theory and practice. London: Kogan Page.

Mor, Y., Ferguson, R., \& Wasson, B. (2015). Learning design, teacher inquiry into student learning and learning analytics: A call for action. British Journal of Educational Technology, 46(2), 221-229.

Mor, Y., Craft, B., \& Hernández-Leo, D. (2013). Editorial: The art and science of learning design. Research in Learning Technology, 21, 22513.

Papanikolaou, K., Makri, K., \& Roussos, P. (2017). Learning design as a vehicle for developing TPACK in blended teacher training on technology enhanced learning. International Journal of Educational Technology in Higher Education, 14(1), 34.

Persico, D., \& Pozzi, F. (2015). Informing learning design with learning analytics to improve teacher inquiry. British Journal of Educational Technology, 46(2), 230-248. 
Persico, D., Pozzi, F., \& Goodyear, P. (2018). Teachers as designers of TEL interventions. British Journal of Educational Technology, 49(6), 975-980.

Popp, J. S., \& Goldman, S. R. (2016). Knowledge building in teacher professional learning communities: Focus of meeting matters. Teaching and Teacher Education, 59, 347-359.

Prestridge, S. (2019). Categorising teachers' use of social media for their professional learning: A self-generating professional learning paradigm. Computers \& Education. 129 (Feb. 2019), 143-158

Prieto, L. P., Sharma, K., Dillenbourg, P., \& Rodriquez-Triana, M. J. (2016). Teaching analytics: towards automatic extraction of orchestration graphs using wearable sensors. In Proceedings of the sixth international conference on learning analytics \& knowledge (pp. 148-157). ACM.

Rienties, B., \& Toetenel, L. (2016). The impact of learning design on student behaviour, satisfaction and performance: A cross-institutional comparison across 151 modules. Computers in Human Behavior, 60, 333-341.

Rienties, B., Herodotou, C., Olney, T., Schencks, M., \& Boroowa, A. (2018). Making Sense of Learning Analytics Dashboards: A Technology Acceptance Perspective of 95 Teachers. The International Review of Research in Open and Distributed Learning, 19(5).

Rodríguez-Triana, M. J., Martínez-Monés, A., Asensio-Pérez, J. I., \& Dimitriadis, Y. (2015). Scripting and monitoring meet each other: Aligning learning analytics and learning design to support teachers in orchestrating CSCL situations. British Journal of Educational Technology, 46(2), 330-343

Sergis, S., \& Sampson, D. G. (2017). Teaching and learning analytics to support teacher inquiry: A systematic literature review. In Learning analytics: Fundaments, applications, and trends (pp. 25-63). Springer, Cham.

Scardamalia, M., \& Bereiter, C. (2006). Knowledge building: Theory, pedagogy, and technology. In R. K. Sawyer (Ed.), The Cambridge handbook of the learning sciences (pp. 97-118). New York, NY: Cambridge University Press.

Tseng, F. C., \& Kuo, F. Y. (2014). A study of social participation and knowledge sharing in the teachers' online professional community of practice. Computers \& Education, 72, 37-47.

Van Gasse, R., Vanlommel, K., Vanhoof, J., \& Van Petegem, P. (2017). Unravelling data use in teacher teams: How network patterns and interactive learning activities change across different data use phases. Teaching and Teacher Education, 67, 550-560.

Vatrapu, R., Teplovs, C., Fujita, N., \& Bull, S. (2011). Towards visual analytics for teachers' dynamic diagnostic pedagogical decision-making. In Proceedings of the 1st International Conference on Learning Analytics and Knowledge (pp. 93-98). ACM.

Vescio, V., Ross, D., \& Adams, A. (2008). A review of research on the impact of professional learning communities on teaching practice and student learning. Teaching and Teacher Education, 24(1), 80-91.

Villasclaras-Fernández, E., Hernández-Leo, D., Asensio-Pérez, J. I., \& Dimitriadis, Y. (2013). Web Collage: An implementation of support for assessment design in CSCL macro-scripts. Computers \& Education, 67, 79-97. 
Voogt, J., Laferrière, T., Breuleux, A., Itow, R. C., Hickey, D. T., \& McKenney, S. (2015). Collaborative design as a form of professional development. Instructional science, 43(2), 259-282.

Wenger, E. (1998). Communities of practice: Learning, meaning, and identity. Cambridge University Press.

Wise, A. F., Vytasek, J. M., Hausknecht, S., \& Zhao, Y. (2016). Developing Learning Analytics Design Knowledge in the" Middle Space": The Student Tuning Model and Align Design Framework for Learning Analytics Use. Online Learning, 20(2), 155-182.

Yang, S. H. (2016). Conceptualizing effective feedback practice through an online community of inquiry. Computers \& Education, 94, 162-177.

Yin, R. K. (2009). Case study research: Design and methods (applied social research methods). London and Singapore: Sage.

\section{Appendix}

Table A.1 Collective process: Instrument developed based on the CHAT framework to evaluate the usefulness of the community awareness dashboard

Please rate the usefulness of the following elements from 1 (Strongly disagree) to 5 (Strongly agree).

(Likert scale 1-5: 1. Strongly disagree, 2. Disagree 3. Neither agree Nor Disagree, 4. Agree. 5. Strongly agree)

Items

Designs tab

1. "Designs_characteristics" helps me to understand the overall design activity in my community.

2. "Most-viewed designs" helps me to identify popular designs of my community.

3. "Most-reused desings" helps me to identify useful designs of the community

4. All in all the members tab helped me to acquire aggregated and detail information for the emerging activity about the created designs.

Members tab

1. "Members_characteristics" helped me to understand in overall the activities of the members in this community

2. "Top_contributors" helps me to identiy key members of the community.

3. "Top commenters" helps me to identify key members who reflect on the content of the created designs.

4. All in all the members tab helped me to acquire aggregated and detail information for the emerging activity of the members.

Tools tab

1."Tool evolution" helps me understand how the community uses different tools over time.

2. "Tools use" helps me to understand what the most popular tools in the community are.

3. All in all the tools tab helped me to acquire aggregated and detail information for the emerging activity of tools used in the community

$(N=23$, Cronbach's alpha=.74)

Table A.2 Collective inquiry process: Interview questions about the collective teacher inquiry $(N=7)$.

\begin{tabular}{|l|l|}
\hline & Collective teacher inquiry \\
\hline 1. & Please explain your experience about the group reflections in the project. \\
\hline a. & Which is the utility of having access to documented inquiry cycles of other teachers? \\
\hline b. & Are there benefits or challenges to reuse others' documented inquiries? \\
\hline c. & $\begin{array}{l}\text { Are you willing to share your documented inquiries with other teachers within your school? Why? And outside } \\
\text { the school? }\end{array}$ \\
\hline
\end{tabular}

Table A.3 Inquiry process: Interview questions about the teacher inquiry process $(N=7)$.

\section{\begin{tabular}{|l|l|l}
\hline 1. & Technology-supported teacher inquiry \\
\hline
\end{tabular}}




\begin{tabular}{|l|l|}
\hline a. & $\begin{array}{l}\text { Please explain your experience with the design, implementation and reflection of the learning designs which you } \\
\text { created. Which were the main challenges or problems? Did you overcome them? How? }\end{array}$ \\
\hline b. & What could be the role of technology to facilitate a teacher-inquiry cycle? \\
\hline c. & $\begin{array}{l}\text { What do you think are the challenges for you or other teachers to perform inquiries with technology? (e.g. with the } \\
\text { use of the TILE tool, with the use of Google forms, PyramidApp to collect data) }\end{array}$ \\
\hline 2. & Data-informed teacher inquiry \\
\hline a. & Which collected data and technologies were especially useful for the improvement of your design? \\
\hline b. & Can you give an example of data use for improving your learning design? \\
\hline
\end{tabular}

Table A.5 Main topics and sample of teachers' answers about the teacher inquiry process based on interviews and questionnaire.

\begin{tabular}{|c|c|c|c|c|c|}
\hline \multicolumn{3}{|c|}{ Questionnaire } & \multicolumn{3}{|c|}{ Interviews } \\
\hline \multirow[t]{2}{*}{ Topics } & Explanation & Excerpts & \multirow[b]{2}{*}{$\begin{array}{l}\text { Topics } \\
\text { Documentation } \\
\text { for review }\end{array}$} & \multirow[b]{2}{*}{$\begin{array}{l}\text { Explanation } \\
\text { Facilitating } \\
\text { documentation for } \\
\text { reflection. }\end{array}$} & \multirow[b]{2}{*}{$\begin{array}{l}\text { Excerpts } \\
\text { "If you have well } \\
\text { documented the whole } \\
\text { process, then you can } \\
\text { make a summary. It is } \\
\text { something that could } \\
\text { help in future plans." } \\
\text { TS1.e }\end{array}$} \\
\hline & \begin{tabular}{|l|} 
Facilitating \\
systematic \\
way to collect \\
student data.
\end{tabular} & $\begin{array}{l}\text { "It allows to collect data in a } \\
\text { systematic way. We often do } \\
\text { it only in an intuitive way } \\
\text { and this way even allows } \\
\text { you to reflect in real time, } \\
\text { when you have fresher the } \\
\text { inputs received from the } \\
\text { students." TS1.c }\end{array}$ & & & \\
\hline $\begin{array}{l}\text { Expectations \& } \\
\text { Objective } \\
\text { evaluations (3) }\end{array}$ & $\begin{array}{l}\text { Facilitating } \\
\text { the connection } \\
\text { between } \\
\text { teachers' } \\
\text { expectations } \\
\text { and evaluation }\end{array}$ & $\begin{array}{l}\text { “A good summary of } \\
\text { learning objectives and } \\
\text { teacher expectations and } \\
\text { how the activity was in } \\
\text { reality." TS1.k }\end{array}$ & $\begin{array}{l}\text { Collecting } \\
\text { objective data }\end{array}$ & $\begin{array}{l}\text { Facilitating the } \\
\text { collection of } \\
\text { objective student } \\
\text { data. }\end{array}$ & $\begin{array}{l}\text { "Surely the teachers } \\
\text { would have more } \\
\text { objective data." TS1.c }\end{array}$ \\
\hline Practical (3) & $\begin{array}{l}\text { Practical way } \\
\text { to reflect on } \\
\text { learning } \\
\text { design }\end{array}$ & $\begin{array}{l}\text { "It is practical as it forces } \\
\text { you to think about the } \\
\text { activity from the beginning, } \\
\text { do not do the activity } \\
\text { directly, but it forces you to } \\
\text { write the goal and turn } \\
\text { around before moving on." } \\
\text { TS1.g }\end{array}$ & $\begin{array}{l}\text { Awareness / } \\
\text { Orientation: }\end{array}$ & $\begin{array}{l}\text { Provides orientation } \\
\text { and key elements } \\
\text { for reflection. }\end{array}$ & $\begin{array}{l}\text { The fact that it is } \\
\text { separated in different } \\
\text { steps helps you to be } \\
\text { more aware of what } \\
\text { you're doing" TS2.a }\end{array}$ \\
\hline \multirow[t]{2}{*}{$\begin{array}{l}\text { Awareness / } \\
\text { Orientation } \\
(3):\end{array}$} & $\begin{array}{l}\text { Provides } \\
\text { orientation } \\
\text { and key } \\
\text { elements for } \\
\text { reflection }\end{array}$ & $\begin{array}{l}\text { "It summarizes the most } \\
\text { important elements } \\
\text { (problem, questions, data, } \\
\text { reflections) to improve the } \\
\text { design." TS2.a }\end{array}$ & $\begin{array}{l}\text { Limited time/ } \\
\text { Many students }\end{array}$ & $\begin{array}{l}\text { Lack of time and } \\
\text { large student } \\
\text { cohorts hinder } \\
\text { frequent teacher } \\
\text { inquiries. }\end{array}$ & $\begin{array}{l}\text { "The time to implement } \\
\text { it. Moving from theory } \\
\text { to practice is difficult, } \\
\text { time is an impediment." } \\
\text { TS1.b }\end{array}$ \\
\hline & & & $\begin{array}{l}\text { Technical } \\
\text { difficulties }\end{array}$ & $\begin{array}{l}\text { Difficulties and } \\
\text { familiarity with ICT } \\
\text { tools. }\end{array}$ & $\begin{array}{l}\text { "In the implementation, } \\
\text { I had some difficulties } \\
\text { but basically technical } \\
\text { difficulties." TS2.d }\end{array}$ \\
\hline
\end{tabular}

Table A.6 Main topics and sample of teachers' answers about data use for learning design based on questionnaire and interviews.

\begin{tabular}{|l|l|l|l|l|l|}
\hline \multicolumn{2}{|c|}{ Questionnaire } & \multicolumn{3}{c|}{ Interviews } \\
\hline Topics & Explanation & Excerpts & Topics & Explanation & Excerpts \\
\hline
\end{tabular}




\begin{tabular}{|c|c|c|c|c|c|}
\hline $\begin{array}{l}\text { Collecting } \\
\text { information (5) }\end{array}$ & $\begin{array}{l}\text { Facilitating } \\
\text { the collection } \\
\text { of student } \\
\text { information. }\end{array}$ & $\begin{array}{l}\text { "The most interesting thing } \\
\text { about the tool is to collect the } \\
\text { information generated during } \\
\text { an activity in which it cannot } \\
\text { normally be collected. Very } \\
\text { interesting to be able to apply } \\
\text { it to classes." }\end{array}$ & $\begin{array}{l}\text { Student } \\
\text { misunderstanding }\end{array}$ & $\begin{array}{l}\text { Identifying } \\
\text { student } \\
\text { misunderstandings } \\
\text {. }\end{array}$ & $\begin{array}{l}\text { The monitoring of } \\
\text { discussions allows } \\
\text { seeing that students did } \\
\text { not understand the } \\
\text { concept which you } \\
\text { wanted to transmit. }\end{array}$ \\
\hline $\begin{array}{l}\text { Student } \\
\text { feedback (6) }\end{array}$ & $\begin{array}{l}\text { Using student } \\
\text { feedback for } \\
\text { informing } \\
\text { learning } \\
\text { design. }\end{array}$ & $\begin{array}{l}\text { "It is important to have } \\
\text { feedback from the students to } \\
\text { know whether the same } \\
\text { activity should be proposed } \\
\text { again or modified." }\end{array}$ & Student feedback & $\begin{array}{l}\text { Using student } \\
\text { feedback for } \\
\text { informing learning } \\
\text { design. }\end{array}$ & $\begin{array}{l}\text { "I used more the } \\
\text { student feedback than } \\
\text { the other provided } \\
\text { data." TS2.d }\end{array}$ \\
\hline $\begin{array}{l}\text { Reflections / } \\
\text { Improvement } \\
\text { (3) }\end{array}$ & $\begin{array}{l}\text { Reflection on } \\
\text { learning } \\
\text { designs } \\
\text { informs their } \\
\text { improvement. }\end{array}$ & $\begin{array}{l}\text { "Reflecting on any activity } \\
\text { carried out in the classroom } \\
\text { always allows for } \\
\text { improvement." }\end{array}$ & $\begin{array}{l}\text { Time \& } \\
\text { Instructions }\end{array}$ & $\begin{array}{l}\text { Important to } \\
\text { consider time \& } \\
\text { instructions during } \\
\text { enactment. }\end{array}$ & $\begin{array}{l}\text { "They indicated that } \\
\text { they were stressed and } \\
\text { had not given time to } \\
\text { develop a good } \\
\text { argument." TS2.a }\end{array}$ \\
\hline $\begin{array}{l}\text { Time \& } \\
\text { Instructions (2) }\end{array}$ & $\begin{array}{l}\text { Important to } \\
\text { consider time } \\
\& \\
\text { instructions } \\
\text { during } \\
\text { enactment. }\end{array}$ & $\begin{array}{l}\text { "It is necessary to find the } \\
\text { way to adjust the time and to } \\
\text { explain with ease the } \\
\text { operation of the activity to } \\
\text { the students." }\end{array}$ & & & \\
\hline
\end{tabular}

Table A.7 Inquiry process in the MOOC: Questionnaire about perceived usefulness of ILDE tools Please, let us know your level of agreement about the following statements related with the ILDE. (Likert scale 1-7: 1. Strongly disagree, 2. Disagree 3. Somewhat disagree, 4. Neither agree Nor Disagree, 5. Somewhat agree, 6. Agree. 7. Strongly agree)

\section{Items}

1. The conceptualization features of the ILDE are useful.

2. The authoring features of the ILDE are useful.

3. The implementation features of the ILDE are useful.

$(N=33$, Cronbach's alpha $=.85)$

Table A.8 MOOC community: Sample of learning design artifacts

\begin{tabular}{|c|c|c|c|}
\hline User id & Conceptualization / Problem & Design / Solution & Educational Level \\
\hline 1533 & $\begin{array}{l}\text { CL activity about students who do not } \\
\text { know each other. Triggering more } \\
\text { reflections. }\end{array}$ & $\begin{array}{l}\text { Pyramid activity with } \\
\text { Pyramid app }\end{array}$ & Higher Education \\
\hline 2785 & $\begin{array}{l}\text { Promote more interactions and } \\
\text { reflections between students with } \\
\text { different ages and interests. }\end{array}$ & $\begin{array}{l}\text { Pyramid activity with } \\
\text { PyramidApp tool }\end{array}$ & Higher Education \\
\hline 2788 & $\begin{array}{l}\text { More arguments and elaboration on } \\
\text { teaching methods. }\end{array}$ & Jigsaw activity in Moodle & Teacher training \\
\hline 1548 & CL activity about reflection on arts. & $\begin{array}{l}\text { Jigsaw which includes the } \\
\text { use of Kahoot }\end{array}$ & Teacher training \\
\hline 1590 & $\begin{array}{l}\text { CL activity about threats of social } \\
\text { networking. }\end{array}$ & Jigsaw activity in Moodle & Secondary Education \\
\hline 1653 & $\begin{array}{l}\text { Teamwork on constructing UML } \\
\text { diagrams. More experience in } \\
\text { teamwork. }\end{array}$ & Jigsaw activity in Moodle & Higher Education \\
\hline 1623 & $\begin{array}{l}\text { Understanding key concepts of the } \\
\text { causes and effects of overpopulation. }\end{array}$ & $\begin{array}{l}\text { Pyramid activity with } \\
\text { PyramidApp }\end{array}$ & Not specified \\
\hline
\end{tabular}




\begin{tabular}{|l|l|l|l|}
\hline 1868 & $\begin{array}{l}\text { Reflect on a theoretical framework with } \\
\text { a collaborative activity. Increase } \\
\text { student participation. }\end{array}$ & $\begin{array}{l}\text { Pyramid activity with } \\
\text { PyramidApp }\end{array}$ & Higher Education \\
\hline 1542 & Gamification to motivate students. & Jigsaw activity in Moodle & Higher Education \\
\hline 3115 & $\begin{array}{l}\text { Develop communication skills with } \\
\text { active interactions. }\end{array}$ & Jigsaw activity in Moodle & Secondary Education \\
\hline
\end{tabular}

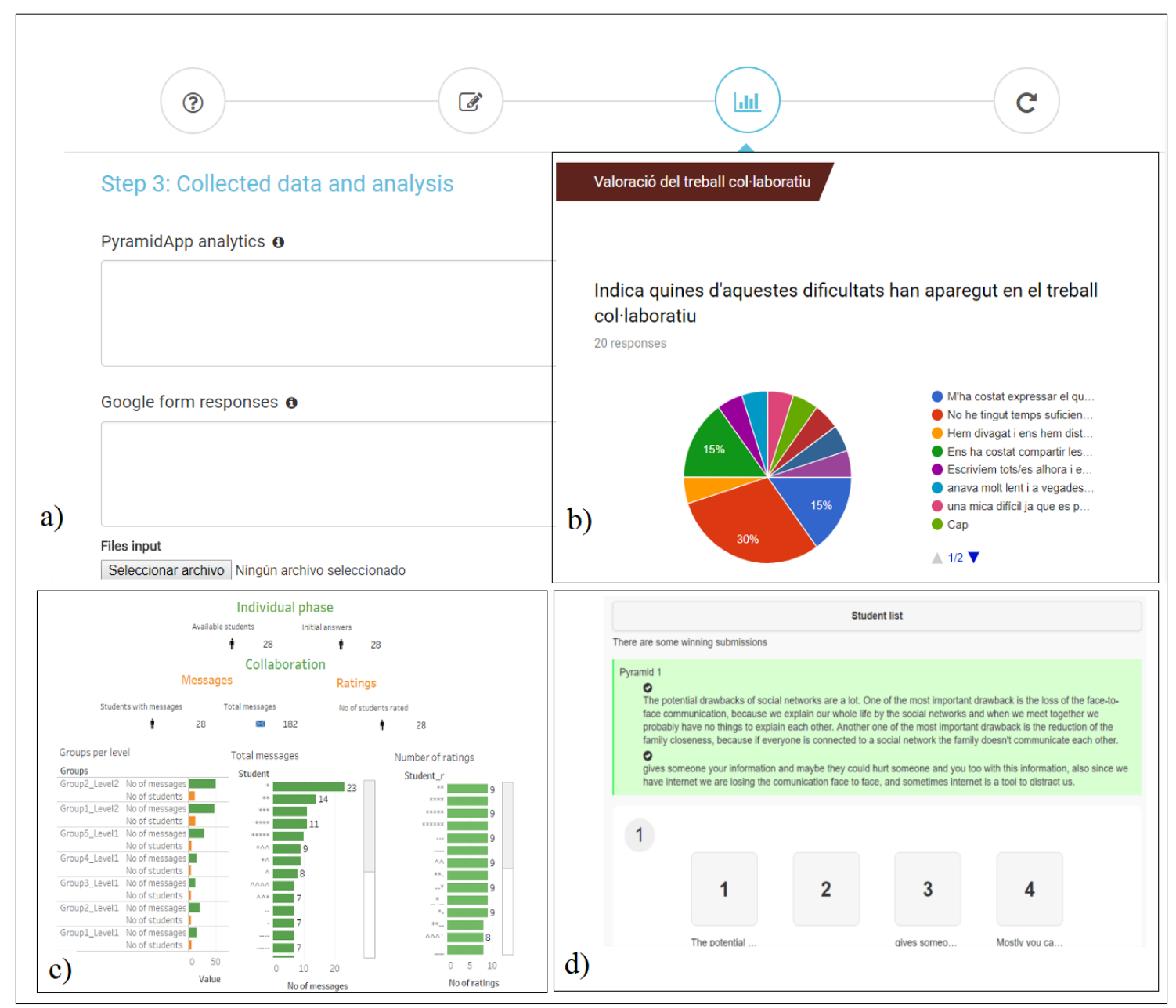

Figure A.1 Example of student data in the 3rd step of the TILE tool. a) TILE tool; b) Student feedback; c) Engagement analytics during the collaborative activity; d) Content of student answers and discussions in the collaborative activity 


\section{Acknowledgments}

Authors would like to thank all the teachers who participated in the communities studied as well as Juan Asensio-Perez, Sara Villagra-Sobrino, Pablo Abenia and Judit Martínez. DHL is a Serra Húnter Fellow. This work has been partially funded by "la Caixa Foundation" (CoT project, 100010434); by the European Regional Development Fund and the National Research Agency of the Spanish Ministry of Science, Innovation and Universities, under project grants TIN 201453199-C3-3-R, TIN2014-53199-C3-2-R, TIN 2017-85179-C3-2-R, TIN 2017-85179-C3-3-R, MDM-2015-0502 